Article

\title{
Collective Renewable Energy Prosumers and the Promises of the Energy Union: Taking Stock
}

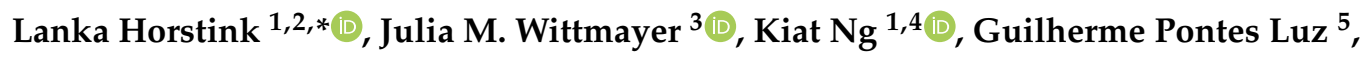 \\ Esther Marín-González ${ }^{5}{ }^{\circledR}$, Swantje Gährs ${ }^{6}$, Inês Campos ${ }^{5}{ }^{\circledR}$, Lars Holstenkamp ${ }^{7}{ }^{\circledR}$, \\ Sem Oxenaar ${ }^{3}$ and Donal Brown ${ }^{8}$ iD \\ 1 Faculty of Engineering, University of Porto (FEUP), Rua Dr. Roberto Frias, 4200-465 Porto, Portugal; \\ kiatng@fe.up.pt \\ 2 Institute of Social Sciences, University of Lisbon (ICS-UL), Av. Professor Aníbal de Bettencourt, 9, \\ 1600-189 Lisboa, Portugal \\ 3 DRIFT—Dutch Research Institute for Transitions, Erasmus University Rotterdam, Postbus 1738, \\ 3000 DR Rotterdam, The Netherlands; j.m.wittmayer@drift.eur.nl (J.M.W.); oxenaar@drift.eur.nl (S.O.) \\ 4 CIIMAR-Interdisciplinary Centre of Marine and Environmental Research, University of Porto, Terminal de \\ Cruzeiros de Matosinhos, Av. General Norton de Matos s/n, 4450-208 Matosinhos, Portugal \\ 5 Centre for Ecology, Evolution and Environmental Changes (CE3C), Faculty of Sciences of Lisbon University, \\ Campo Grande, 1749-016 Lisboa, Portugal; gpluz@fc.ul.pt (G.P.L.); emgonzalez@fc.ul.pt (E.M.-G.); \\ iscampos@fc.ul.pt (I.C.) \\ 6 Institute for Ecological Economy Research (IÖW), Potsdamer Str. 105, 10785 Berlin, Germany; \\ swantje.gaehrs@ioew.de \\ 7 Institute of Banking, Finance and New Venture Management, Leuphana University of Lüneburg, \\ Universitätsallee 1, 21335 Lüneburg, Germany; holstenkamp@uni.leuphana.de \\ 8 Sustainability Research Institute, University of Leeds, Leeds LS2 9JT, UK; D.L.Brown@leeds.ac.uk \\ * Correspondence: lanka.horstink@ics.ulisboa.pt; Tel.: +351-919852781
}

Received: 1 November 2019; Accepted: 30 December 2019; Published: 15 January 2020

check for updates

\begin{abstract}
A key strategy in the European Union's ambition to establish an 'Energy Union' that is not just clean, but also fair, consists of empowering citizens to actively interact with the energy market as self-consumers or prosumers. Although renewable energy sources (RES) prosumerism has been growing for at least a decade, two new EU directives are intended to legitimise and facilitate its expansion. However, little is known about the full range of prosumers against which to measure policy effectiveness. We carried out a documentary study and an online survey in nine EU countries to shed light on the demographics, use of technology, organisation, financing, and motivation as well as perceived hindering and facilitating factors for collective prosumers. We identified several internal and external obstacles to the successful mainstreaming of RES prosumerism, among them a mismatch of policies with the needs of different RES prosumer types, potential organisational weaknesses as well as slow progress in essential reforms such as decentralising energy infrastructures. Our baseline results offer recommendations for the transposition of EU directives into national legislations and suggest avenues for future research in the fields of social, governance, policy, technology, and business models.
\end{abstract}

Keywords: renewable energy prosumer; energy transition; collective prosumer; energy union; community energy

\section{Introduction}

The European Commission (EC) is spearheading the EU's plan to 'lead the clean energy transition, not only adapt to it' [1]. In 2016, the EC started developing a 'Clean Energy Package' that has now been finalised (the eight legislative acts that compose the Clean Energy package were recently concluded 
with the adoption of the recast of the Renewables Directive (RED II), the new Governance Regulation of the Energy Union and Climate Action, the new Energy Efficiency Directive as well as the recast of the Electricity Directive [2]), completely overhauling the EU's energy policy framework, with the objectives of reducing $\mathrm{CO}_{2}$ emissions by $40 \%$, increasing the share of renewable energy sources to $32 \%$, and improving energy efficiency by $32.5 \%$ by 2030 . The vision of an 'Energy Union' - providing all EU consumers with secure, sustainable, competitive, and affordable energy-includes an appropriate regulatory framework, strategic investments to innovate the EU's energy system, and an integrated multi-level energy governance framework. Having promised safe, viable, and accessible energy supply for all, the EC and EU countries are keen on embedding fairness, inclusiveness, local economy stimuli, and job growth in the transition toward a climate-neutral energy system [3].

The Energy Union aims to stimulate the involvement of energy consumers in the energy market 'to generate electricity for their own consumption, store it, share it, consume it or sell it back to the market' [4]. At the very least, citizens are expected to be 'active customers' (i.e., not merely buying electricity, but participating either in energy production, demand-response, or energy efficiency schemes: see the new recast EU Electricity Directive [3]), at best they will become what the EC is now calling 'renewables self-consumers', who generate, store, and/or sell self-generated electricity from renewable energy sources (RES) as per the RED II Directive [5], and which in the scientific literature is also referred to as an 'energy prosumer' [6]. By placing citizens at the centre of the Energy Union, and giving them the right to produce, store, or sell their own energy, whether individually or collectively, EU institutions are betting on a more rapid take-up of renewables in the energy system [2,5].

With EU countries being encouraged to support decentralised renewable energy through the relaxing of rules and/or the offering of incentives for RES self-consumption, the development of energy cooperatives and energy communities is accelerating all across Europe [7]. Representing approximately one million citizens, the European Federation of renewable energy cooperatives (REScoop.eu), established as recently as 2013, has rapidly grown to a network of 1500 renewable energy cooperatives and energy communities [8]. The pace at which the adoption of renewable energy has spread through Europe, additionally facilitated by the unexpected drop in prices of a number of RES technologies [9], has taken legislators and policy-makers by surprise, creating a fertile ground for ad hoc rather than strategic responses [10]. Important dimensions of prosumerism, such as the development of technology, the choice of organisational models, and innovation in funding solutions are still a long way from stabilising [7].

A number of promising case studies on community energy initiatives (e.g., [11-13]) as well as helpful analyses of the mitigating factors at work (see for instance [14-16]) support the claim that placing citizens at the core of a clean and fair energy transition is key to its success. There are, however, no reviews of the full range of collective prosumers (i.e., non-household) beyond the better-known energy cooperatives: who are they, what are their characteristics, behaviour, needs, and socio-economic impact? How does one collective prosumer initiative differ from others? Which of these initiatives should be incentivised and how? This gap in our knowledge makes it difficult to assess RES prosumerism's contribution to an energy transition that is expected to meet ambitious social, economic, and ecological objectives as well as measure the effectiveness of the policies being put in place to stimulate the prosumer phenomenon. These issues are especially salient when considering the accelerated timeframe of the Energy Union and the expected growth-spurt in prosumer initiatives once the Clean Energy Package is in place. This article aims to address this gap in the literature by providing a much-needed overview of the diversity of collective RES prosumer initiatives as well as a stock-take of the demographic, technological, organisational, financial, motivational, and hindering/facilitating factors that characterise them, and assess how the state of the art aligns with current energy policies and incentives. Our research, part of a larger project aiming to provide a framework of incentive structures for collective prosumers, is guided by the following question:

What is the current state of play for collective forms of RES prosumerism in Europe considering the demands and promises of the Energy Union? 
The article is structured as follows: in Section 2, we will embed our research within its scope. We will then, in Section 3, present the methodology employed to survey a diversity of RES prosumer initiatives in nine countries in Europe: Belgium (BE), Croatia (HR), France (FR), Germany (DE), Italy (IT), the Netherlands (NL), Portugal (PT), Spain (ES), and the United Kingdom (UK). In Section 4, we present the results of our collective RES prosumer characterisation, the most significant of which are subsequently discussed in light of their policy implications in Section 5. In Section 6, we sum up our key conclusions and make some policy recommendations to support the continued growth of RES prosumerism in the EU, while safeguarding the vision of the Energy Union.

\section{Background Review of Renewable Energy Sources (RES) Prosumerism}

Reviewing nine EU countries as well as the EU as a whole, we found that differences in the take-up of RES prosumerism can be attributed among others to the varying investment in RES [17], energy path dependencies related to the natural resources available in the different countries (see for example [18]), as well as cultural factors (e.g., [19,20]). Of the countries studied by us, only Portugal and Croatia approached the mark of a 30\% share of renewable energy sources in gross final consumption of energy, while France, Spain, and Germany scored around the EU average (17.53\%), and the United Kingdom, Italy, the Netherlands, and Belgium scored closer to the 9\% mark [21]. Each country's context is reflected in the overall energy forms that it consumes (i.e., countries with good hydric conditions have a high production of hydro-electricity, countries that (historically) have access to natural gas (NL, UK), have gas-driven heating systems, France is largely dependent on its nuclear energy production, etc). Overall, in the EU at the RES level, hydro continues as a leading energy technology, with wind energy coming in either in first or in second place in terms of production capacity. Solar-powered electricity, meanwhile, is growing fast in most countries including the more northern countries [21].

Despite the advances made in restructuring the legislative and policy framework to prepare the EU's clean energy transition, Campos et al. [22] highlighted considerable disparities in legislative and policy support for RES prosumerism in different EU countries, resulting in varying levels of prosumer development. The Clean Energy Package is intended to homogenise the attitude of EU countries toward prosumerism, but it presents several challenges. A key challenge is the imposition of new definitions and rules for individuals as well as collective forms of RES prosumerism that, besides falling short of representing the full diversity of prosumer initiatives sprouting up [10,23-25], is prone to different interpretations in the subsequent transposition to national legislations, a process that must mandatorily be concluded in 2021.

Several reports, reviews, and case studies have tried to produce insight into the drivers, facilitating factors as well as barriers for energy cooperatives and communities. In the sub-sections below, we aim to summarise the most recent and relevant conclusions available from the literature.

\subsection{Sociocultural and Socio-Economic Factors of Prosumerism}

- The institutional features of communities that decide to self-produce will influence/facilitate the process (e.g., whether there is a tradition of cooperatives and/or of collective ownership, how strong is the sense of responsibility for community, etc.) $[19,20]$;

- Social drivers tend to be predominant in community initiatives including in the area of energy (e.g., the need to respond to societal challenges or local social demands) [26]. Bauwens' studies point to a strong desire of energy community initiatives to oversee the (clean) energy supply for their community [27,28];

- A recent review of community energy initiatives found that the latest wave of prosumer initiatives was less tied to advances in renewable energy technology or changes in legislation than to the desire to democratise and decentralise energy [29];

- Aside from responding to societal challenges, energy community initiatives can also bring financial benefits for the community engaged $[30,31]$; 
- Members of energy community initiatives report satisfaction in being part of a community experiment [30] and they tend to be more norm-driven as well as more positive toward an energy system change when part of collective, participative energy projects [28,30,32];

- There are a number of cultural and socio-political barriers to the further development of RES prosumerism, among them the lack of (technical) knowledge in the prosumer initiatives (which are more than often run by volunteers), the spread of misinformation about renewable energy alternatives, and the lack of legitimacy attributed to the cooperative model [30,31];

- A gender imbalance has been posited in energy prosumerism: a relationship has been established between gender and risk of energy poverty [33] as well as between the different ways in which women and men participate in the energy sector and in energy policy decisions, with women generally being highly under-represented in both [34,35].

\subsection{Technical Factors}

- Energy communities are strongly connected to the use of renewable energy [30];

- Collective energy initiatives provide an opportunity for bottom-up innovation in energy efficiency and production and for innovative business models: this topic has been well-researched, not only in terms of grassroots innovation in energy, but also in other key areas of human production (see among others [14,36,37]);

- RES production is increasingly attractive as well as accessible, considering the rapidly falling costs of solar photovoltaic (PV) installations and batteries for storage [31].

\subsection{Financial Factors}

- There is an increasing incentive to self-consume rather than sell to the grid, with feed-in-tariff rates dropping or being abolished, such as in the United Kingdom [31];

- Despite falling costs for RES technologies and accessories, installations can still command considerable investment, in particular, wind parks [30,31].

\subsection{Political Factors}

- There are considerable legal-political implications from relocating control over such a crucial resource as energy to emerging new actors, such as prosumers and prosuming energy communities [9,38]. This may cause governments to hesitate, delay, or stall the development of prosumers. For example, Germany, having 100 years of experience with electricity cooperatives and hundreds of small grid operators, has been under pressure for years by the EU to minimise its number of grid operators [31];

- Policy advocates for RES prosumerism complain that on the one hand, energy infrastructures are insufficiently digitalised, and on the other, existing digital systems (such as trading and billing) are still in the hands of large energy companies [7];

- EU countries are being very slow in phasing out subsidies for fossil fuels, which is creating overcapacity in the energy market, with the EU barely keeping up with the growth of RES [7] (p. 6);

- Due to the liberalisation of energy markets, there is a growing number of purely commercial RES initiatives set up by project developers and incumbent energy companies, in some cases creating legal structures that appear collaborative (i.e., the cooperative), but are not de facto in citizens' hands [31];

- The federation of RES cooperatives and communities complain of rigorous lobbying by large energy companies to reign in the amount of control RES initiatives may command over the energy system [31];

- Energy cooperatives and communities report increasing bureaucratic and regulatory hurdles for starting and running a prosumer initiative, and the current political and legal framework is unstable, with a tapering off of RES prosumer incentives [29-31]; 
Our review reveals several opportunities for the thriving of RES prosumerism, but also an alarming number of barriers and legal/policy contradictions. One concern raised by a number of scientists, policy-makers, as well as representatives of energy communities and cooperatives themselves [31] is how to ensure a more inclusive and democratically-run energy transition such as that being promoted by the EC as a cornerstone of the Energy Union [13,37,39]. For example, should civic-focussed renewable energy initiatives be treated differently than self-interest/profit-focussed initiatives, and who should run the transmission and distribution networks [31]? These are sensitive and under-discussed topics that will influence the pathway of collective RES prosumerism.

In the next section, we present the methodology of our study of collective forms of RES prosumerism.

\section{Methodology}

To elucidate the current state of play for collective (i.e., non-household) prosumer initiatives in Europe, we drew upon an interdisciplinary mix of qualitative and quantitative methods, used in different iterations. Our review was conducted for the whole of the EU as well as zooming in on nine EU countries: BE, HR, FR, DE, IT, NL, PT, ES, and UK. Our survey process included: (i) content preparation; (ii) sampling strategy; (iii) survey administration; (iv) data processing; and (v) data analysis. Our main objective was to obtain an overall picture of the profiles of collective RES prosumer initiatives and the context(s) in which they are developing.

The survey form was designed using a collaborative and iterative approach, drawing on the pooled information needs from the multi-disciplinary research team as well as the knowledge acquired in previous, similar surveys. The survey questionnaire was designed and programmed by us to be answered online and covered six categories, each corresponding to a different information need, with a total of 32 questions (see Appendix A for a full list of the questions).

The main categories were:

1. Control questions (e.g., name and whether the initiative produces/will produce RES);

2. General demographics of collective RES prosumers (e.g., legal form, founding date, location);

3. Use of technology by collective RES prosumers (e.g., energy needs, technologies used);

4. Governance/organisation of collective RES prosumers (e.g., staff characteristics, decision-making mechanisms);

5. Motivation/ambition of the RES prosumer initiative (e.g., reasons to start the initiative); and

6. Hindering and facilitating factors as perceived by collective RES prosumers.

Due to the ambitious nature of our information needs-implying a longer questionnaire- the survey was set up as a multiple case-study. The online, user-friendly survey form was made available in the respondent's own language (a total of eight languages), and its launch was, for most countries, combined with a soft-push approach in two or three steps (telephone calls to leaders of the initiatives, an explanatory email with a link to the survey, and a follow-up email or phone call, as needed).

The final questionnaire is publicly available [23] (pp. 90-116), and has also been submitted as Supplementary Material (Document S1), while examples of questions can be found in Appendix B.

The sample for our self-administered survey was drawn from the nine countries. We included countries with fertile environments for RES prosumerism (DE, UK, NL); two countries with a long history of self-consumption either at an industry or at the regional level but where new prosumer initiatives encounter significant challenges (BE, IT); and four countries where RES prosumerism has only just been legalised: two small countries (HR, PT), and two large ones (FR, ES).

Since there is no established overview of RES prosumer initiatives across Europe, we took an iterative approach to respondent identification. Research teams in the different countries were asked to build exploratory databases of collective RES prosumers in several steps, each being subjected to database analysis to improve these exploratory actor types. In the first iteration, it became clear that our collective forms of RES prosumers were not easily categorised, with attribute overlaps existing between the exploratory types found. In a next step, we decided to distinguish between those actors 
actually prosuming (i.e., producing and consuming energy from renewable energy sources, as an entity or through its members) and those actors influencing RES prosumerism (i.e., facilitating, promoting, financing, supporting, benefitting from, or even hindering) (see Table 1).

Table 1. Working definitions of collective renewable energy sources (RES) prosumers and RES prosumer stakeholders. Source: [23] (pp. 24-25).

\begin{tabular}{c|l}
\hline \multicolumn{1}{c|}{ Broad Actor Type } & \multicolumn{1}{c}{ Working Definition } \\
\hline Collective RES prosumer & $\begin{array}{l}\text { A collective energy actor that produces energy from renewable } \\
\text { sources with the primary objective of providing in its own energy } \\
\text { needs and/or those of its members, and in some cases selling } \\
\text { excess energy to clients, thereby actively participating in the } \\
\text { energy markets. }\end{array}$ \\
\hline RES prosumer stakeholders & $\begin{array}{l}\text { Organisations, institutions, or collectives-or their } \\
\text { representatives-that influence, facilitate, benefit from, and/or may } \\
\text { hinder the development and evolution of RES prosumer initiatives, } \\
\text { in particular, its collective form. }\end{array}$ \\
\hline
\end{tabular}

After a few iterations, our exploratory database analysis identified six broad categories of collective RES prosumer actors capable of describing the RES prosumer initiatives and stakeholders that were collected in our databases across nine EU Member States (Table 2).

Table 2. Key categories of collective RES prosumer actors. Source: [23] (pp. 25-27).

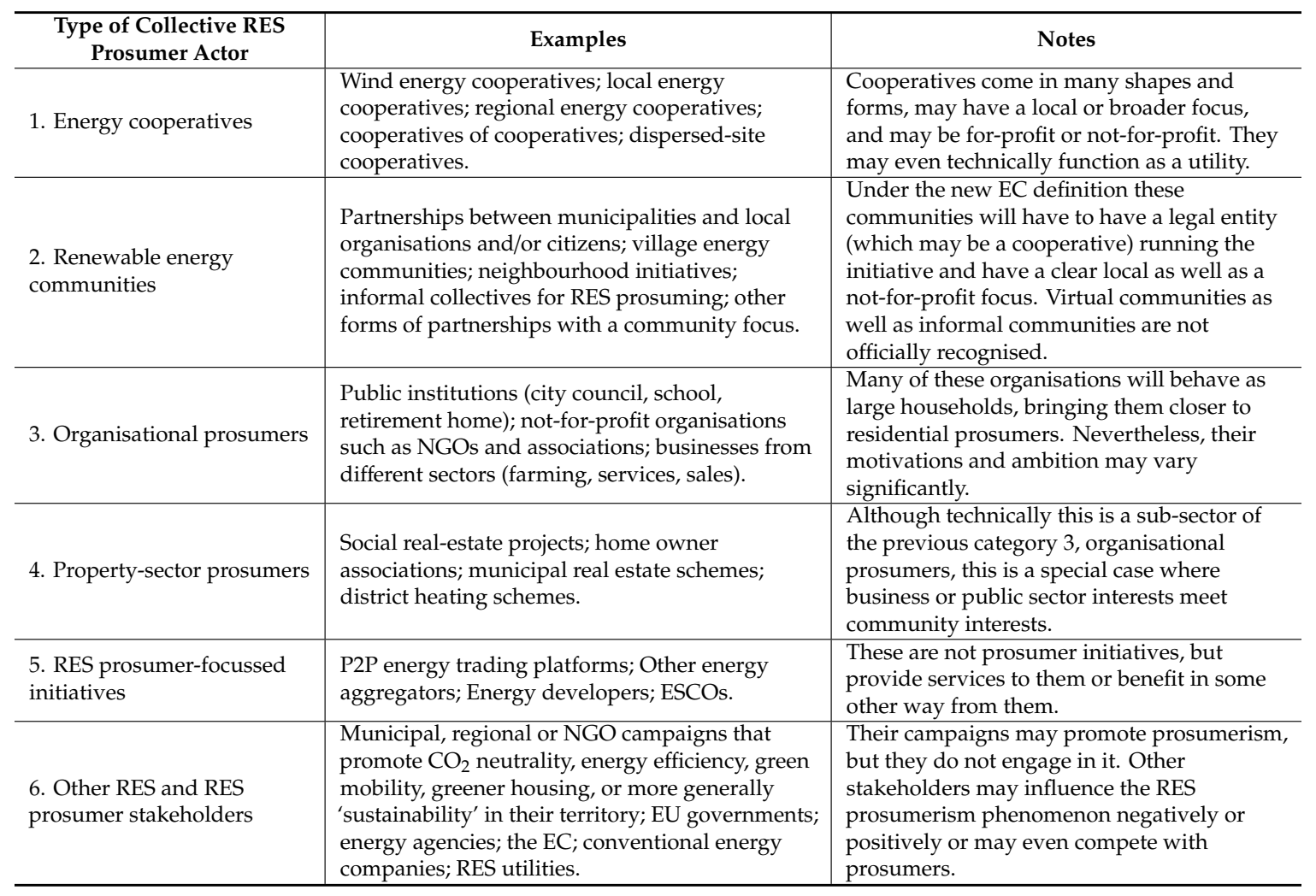

Our final sample population included close to 1000 RES prosumer initiatives. Each country research team had an objective according to the size of their prosumer population (i.e., countries such as Germany, the Netherlands, and the UK contacted hundreds of prosumer initiatives, whereas countries such as Croatia and Portugal did not have a population larger than 20 to 30 initiatives). Sampling was adjusted dynamically according to the type of respondents that answered our survey. A snowball technique was attempted to capture initiatives beyond our sample and countries of focus, but the 
lack of a personalised approach proved to be less successful, and only two additional initiatives, from Denmark and Finland, respectively, responded to this method.

Upon conclusion of the survey, we reclassified the dataset considering the distribution of respondents across countries and the high diversity of legal forms of the initiatives surveyed (see Section 4.1), after which the data were cleaned, tested, treated, plotted, and analysed, using the computational programme MATLAB, complemented with Excel, for our statistical analysis and generating graphs. The full details of how we proceeded can be found in [23]. Our dataset has not been made publicly available, since it contains sensitive information that would identify the initiatives that participated, to which we have promised full anonymity.

In the next section, we present and discuss our main results grouped as follows: distribution of the final dataset; general demographics and operational information; organisational structure; and the key drivers as well as perceived hindering/facilitating factors for developing a RES prosumer initiative.

\section{Results}

\subsection{Distribution of the Final Dataset}

Despite the challenges of an online questionnaire and indirect contact with respondents, the average response rate was $21.8 \%$, corresponding to 198 initiatives that concluded our questionnaire. The number of respondents per country followed the anticipated trend and contacting strategies, with countries with longer histories of prosumerism achieving higher numbers (NL, DE, UK, FR, respectively). Smaller countries and/or countries where RES prosumerism is a more recent phenomenon achieved smaller numbers. With respondents from several countries (UK, NL, DE) warning us about survey fatigue, especially among energy cooperatives, Belgium provided less respondents than would have been expected when looking at the history of prosumerism in that country, while the Netherlands provided more.

We plotted all the answers for the whole dataset, for each of the countries, as well as for the top four legal forms encountered. Overall, and as expected, most of our respondents were energy cooperatives $(60 \%, n=119)$. Their spread across countries more or less followed the trends documented by the few statistical overviews that are available of energy cooperatives, which state that countries like Denmark lead with over 1,000 cooperatives and other northern European countries such as Germany, the UK, and Austria each count hundreds [40], whereas in the south of Europe, the numbers tend not to exceed two dozen [41,42]. There were three other main organisational forms: the for-profit company $(14.5 \%)$; the public institution (9\%); and the private not-for-profit organisation ( $8 \%)$. The prevalence of other legal forms was too residual to draw conclusions on correlations.

We also found and included in our analysis three types of initiatives that come close to a more direct form of energy community: public-private partnerships, partnerships between organisations and/or collectives, and informal civil society initiatives or collectives. Finally, we found RES prosumer initiatives that were run as projects by organisations or collectives (for example, a store that puts a RES installation on its roof as a stand-alone project, or when RES production is just one activity within an organisation promoting sustainable development). In total, we registered around 50 legal forms in the nine countries - of which many were similar, such as the legal form of the association or NGO as well as limited companies and corporations, but some were also quite different, such as the many 'sociétés' in France and the community societies in the UK. In consultation with the research teams in the different countries, we reclassified the legal forms, which resulted in a more manageable list of 10 legal forms (Table 3). 
Table 3. Reclassification of $50+$ legal and organisational forms reported by survey respondents. Source: [23] (p. 54).

\begin{tabular}{|c|c|}
\hline $\begin{array}{l}\text { Legal or other Organisational Forms Given by Respondents } \\
\text { (in Original Language) }\end{array}$ & Reclassification for Data Analysis \\
\hline $\begin{array}{l}\text { SAS (Société par actions simplifiée) cooperative, SAS d'interêt } \\
\text { collectif, Community Benefit Society, Societé cooperative à resp. } \\
\text { limitée, eingetragene Genossenschaft (eG), CVBA, Community } \\
\text { Development Trust, Cooperativa, Industrial Provident Society }\end{array}$ & Cooperative \\
\hline $\begin{array}{l}\text { Societé à resp. limitée, Privatno firma, Malo poduzece, S.A., } \\
\text { ESCo, GmbH \& Co. KG (Kommanditgesellschaft), Gesellschaft } \\
\text { mit beschränkter Haftung (GmbH), Aktiengesellschaft (AG), } \\
\text { Besloten Vennootschap (BV), Limited (Ltd) }\end{array}$ & Company (for-profit) \\
\hline $\begin{array}{l}\text { Publieke organisatie, Staatliche Behörde, Kommune, Overheids } \\
\text { orgaan, Körperschaft des öffentlichen Rechts, Gemeente, } \\
\text { Municipalidade, Gebietskörperschaft, Escola pública }\end{array}$ & Public Institution (incl. local authorities) \\
\hline $\begin{array}{l}\text { Association (ex: of homeowners, sports, ... ), Stichting, } \\
\text { associação, Gesellschaft bürgerlichen Rechts (GbR), } \\
\text { associazione privativa }\end{array}$ & $\begin{array}{l}\text { Private not-for-profit organisations } \\
\text { (e.g., NGO, association, foundation ... ) }\end{array}$ \\
\hline $\begin{array}{l}\text { Social purpose business, Empresa de no lucro, Community } \\
\text { Interest Company }\end{array}$ & $\begin{array}{l}\text { Social Enterprise (for-profit as well as a } \\
\text { social objective) }\end{array}$ \\
\hline Private project & $\begin{array}{l}\text { Project run by an organisation or collective } \\
\text { (i.e., not a legal form) }\end{array}$ \\
\hline $\begin{array}{l}\text { Partnership between family farms and a town community, } \\
\text { partnership between cooperatives, partnership between } \\
\text { companies and community interest companies }\end{array}$ & $\begin{array}{l}\text { Partnership between private organisations } \\
\text { and/or collectives }\end{array}$ \\
\hline Unincorporated community group, informal association & Informal collective or community \\
\hline $\begin{array}{l}\text { Partnership between a GmbH \& Co.KG, partnership between } \\
\text { municipality and other organisations }\end{array}$ & Public-Private-Partnership \\
\hline Other & Other \\
\hline
\end{tabular}

\subsection{Key Demographics and Operational Information on Collective RES Prosumers}

Figure 1 presents the distribution of the top four legal forms across the top four countries in terms of sample size as well as the average distribution for the remaining countries.

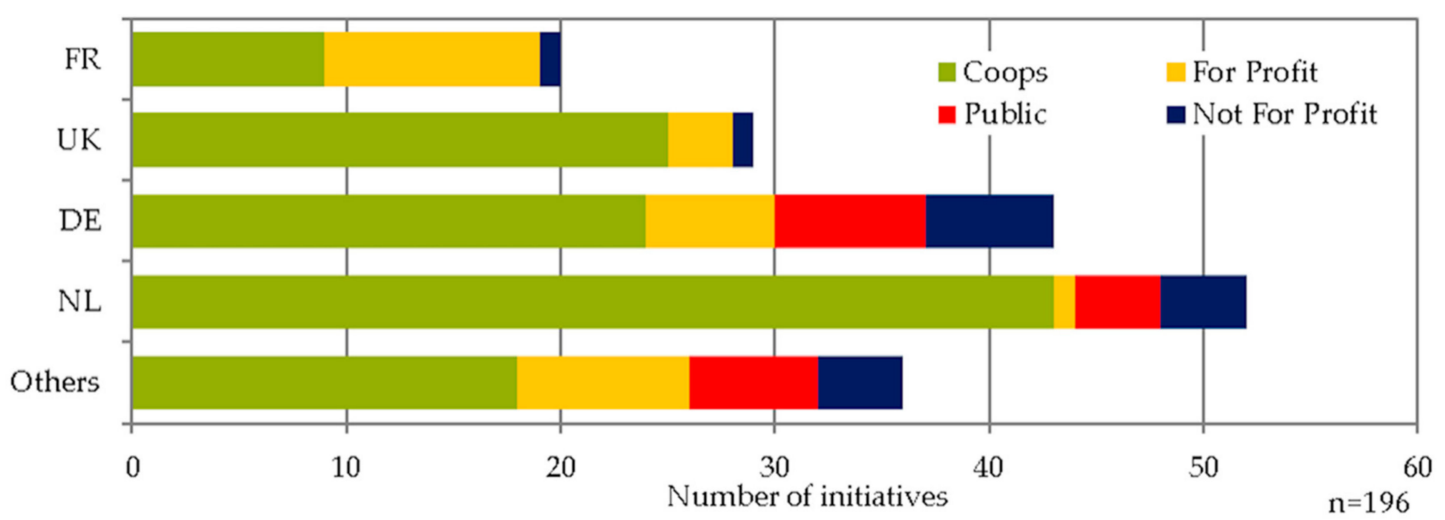

Figure 1. Distribution of legal forms.

While the cooperative was clearly the preferred form for prosumer initiatives in our dataset, nevertheless, in some countries the balance was different than expected, such as in France, which had a higher percentage of initiatives opting for the for-profit/company form, or Croatia, where prosuming initiatives were almost exclusively companies, and finally Spain, where almost half of the respondents 
were public institutions. Even though a considerable number of informal prosumer collectives were contacted, the response rate was low.

Since respondents had space to comment in most of the questions of the survey, we analysed the additional information, which provided more evidence of the apparent mismatch between the legal form and organisational mission:

- Many initiatives highlighted that, independently of their legal form, they considered themselves an energy community (commenting for example: 'we are a community interest association and not-for-profit'). In several cases, instead of giving a straightforward answer to the question about their legal form, respondents would state that 'we are a municipality working with local organisations', 'we are a company/association but run as a cooperative', 'we are a citizens' cooperative', etc. One respondent did not identify as the company it clearly was, instead called their organisation a 'project developer'. As an example of the 'legal form dilemma', see [43] on legal forms chosen by early community energy initiatives in Germany.

- Larger cooperatives, but also municipalities in NL, UK, and BE, reported that increasingly they were opting to create energy companies that will mediate for them in the energy market. They feel that they can move quicker and comply better with legislation by using a company. In this way, cooperatives are hybridising, but keeping their different missions separate, at least legally.

- There were a number of interesting outliers: an association that represents firms located on the same grounds that wish to aggregate their RES production; farming cooperatives that also wish to be prosumers, but not become energy cooperatives; energy suppliers that enable individuals as well as organisations to prosume and buy up the excess energy; and companies taking advantage of pro-renewable energy legislation to set up for-profit RES initiatives that buy up energy from others (an example is Croatia, where biogas is obtained from farmers by companies and then resold).

The growth trend of RES prosumer initiatives (Figure 2) shows a slow growth period until 2010, a period of acceleration followed by a slowing down of growth in the period that the Energy Union and its pillars were debated as well as questioned, a period that starts in 2014, and a possible new growth spurt starting from 2017, with new countries joining the RES prosumerism phenomenon. However, over $12 \%$ of our dataset had not started producing yet, with quite a few initiatives complaining of excessive and complex bureaucracy and/or strict urban planning regulations, some even stating that they had given up on producing due to the above-mentioned barriers compounded with high investment requirements for some of the RES technologies (in particular, wind energy). These initiatives are now focussing on energy advice services and promoting energy efficiency or (e.g., in the UK) considering developing their own RES-ready housing.

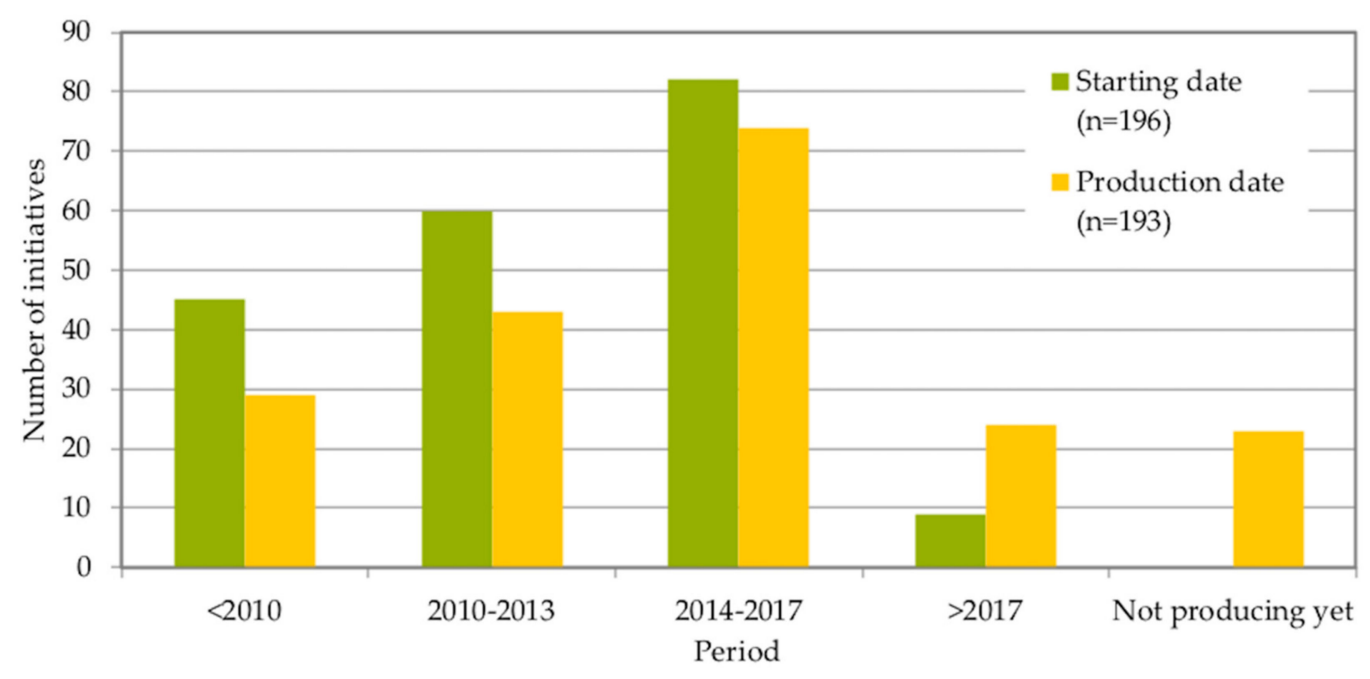

Figure 2. Starting dates of the initiatives and of production. 
In terms of the scale of the initiatives in our dataset, we found $80 \%$ to have a local focus (i.e., town, city, municipality), with $16 \%$ having a regional focus, while a residual percentage had a national focus (3\%). Of those that operated locally, $12 \%$ also reported on regional engagement.

We inquired as to the energy needs addressed by the RES prosumer initiatives in our dataset, and found that RES-powered electricity significantly took the lead, followed by heating and mobility, with cooling appearing in last place (Figure 3). Practically half of our respondents only focussed on producing electricity, while a bit less than half addressed several energy needs simultaneously, the combination of electricity and heating being most popular. The only legal form that did not follow this trend was that of the public institution, where cooling came in third place, and mobility in last. This may be linked to the fact that public institutions most often manage large(r) buildings. In terms of country trends, Germany stood out, with initiatives attributing almost equal importance to electricity and heating, which practically shared first place. The initiatives from the other countries followed the main trend and appeared to have heating trailing significantly behind electricity. This is despite the fact that half of the countries surveyed had a considerable share of heating and cooling from RES sources as a percentage of their total RES consumption: HR (36.6\%); PT (34.4\%); FR (21.4\%); and IT $(20.1 \%)$, with Spain (17.5\%) and Germany (13.4\%) scoring in the mid-range, and all remaining countries having a negligible share of RES in their heating and cooling energy use [21].
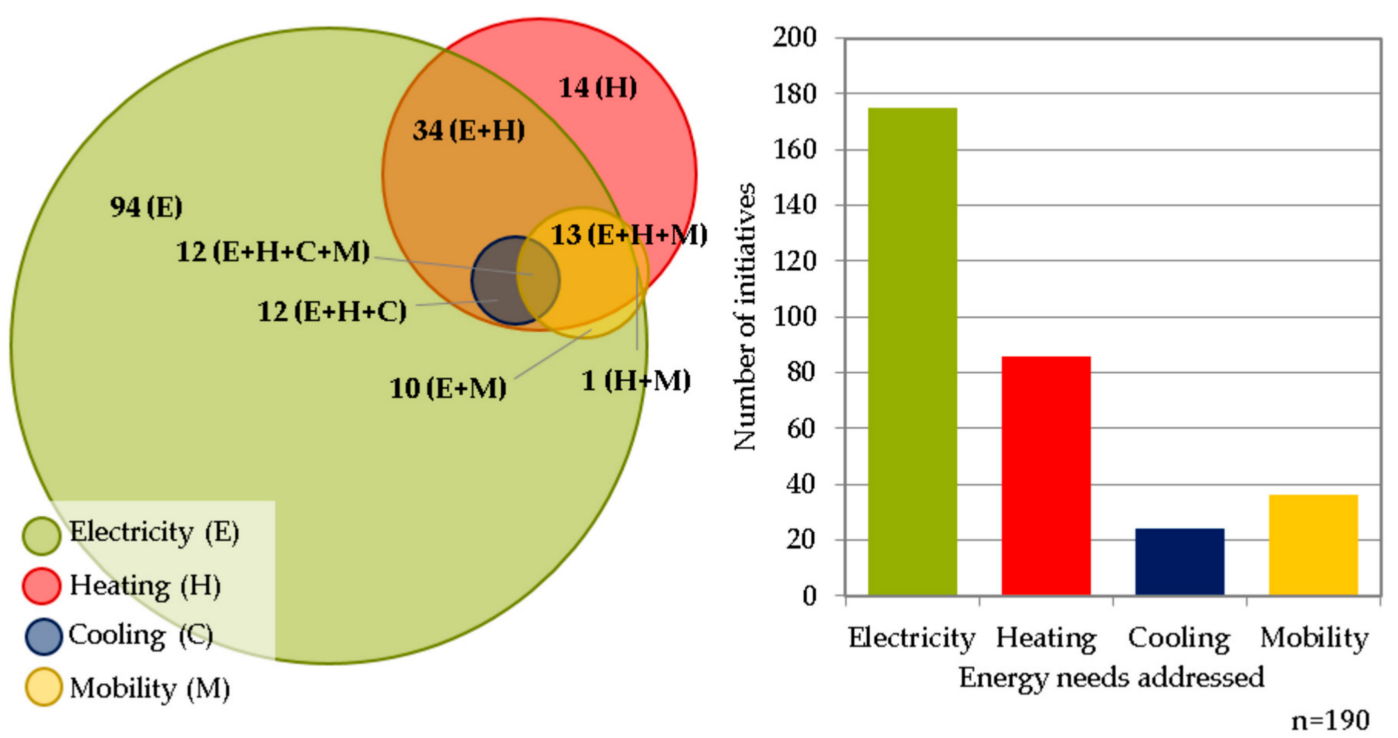

Figure 3. Energy needs addressed by initiative including combined needs.

The overwhelming majority (90\%) of our respondents were producing energy from, or planning to install, solar PV (Figure 4). Nevertheless, one third of respondents were producing energy from wind, which came second in terms of popularity, followed by biomass, storage in batteries, biogas, and solar thermal, respectively. More than half of the prosumer initiatives invested in more than two technologies, with a considerable percentage (20\%) investing in more than four technologies.

Country differences were quite relevant: Belgian respondents reported wind energy as their leading technology, while Croatian respondents focussed on biogas, biomass, and co-generation. The Italian initiatives invested in the highest number of different technologies, each reporting that they were using on average about five to six technologies. The 'big four' from our sample (NL, DE, UK, and FR) as well as Spain reported solar PV as their main technology, but choices for secondary technologies varied significantly: biomass and storage in Germany, wind and storage in the UK, whereas in our French dataset, we found almost no experimentation with energy storage. Even though few initiatives were actively investing in mobility options, several mentioned that they were planning to invest in storage in future. From the trend observed in our dataset, we expect both storage and clean mobility to become more significant. 


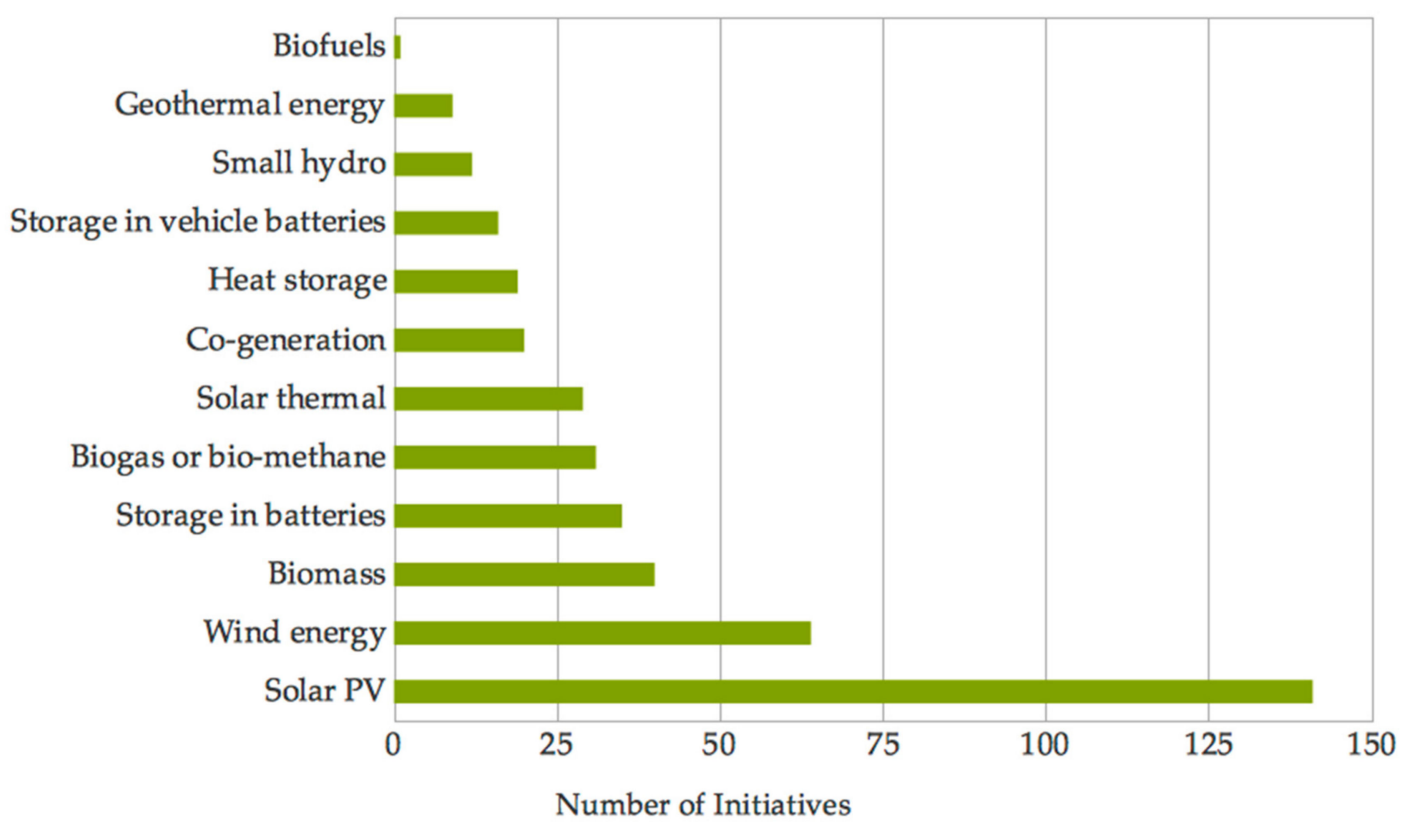

Figure 4. Renewable energy technologies used.

To gauge the different sizes of the RES prosumer initiatives in our dataset, we inquired about the number of members, and client base as well as the number of staff. Our dataset had a predominance of middle-sized initiatives (more than half of the respondents reported having between 51 and 500 members) (Figure 5). Having members, mandatory in most cases, was the norm for cooperatives and the not-for-profit sector (NGOs, associations, foundations, and informal collectives). About half of the cooperatives and the not-for-profit initiatives reported having direct clients besides members. A surprisingly high number of companies reported not having direct clients, but when verifying their websites, we concluded that there may have been a miscommunication due to our use of the term 'direct client', since they did report having clients on their websites. In terms of staff size, while the average number of staff members was low (13, with a median of eight), when compared to the member sizes of the initiatives, there were extreme outliers (an overall range from 1 to 150 staff members) as well as differences between companies, cooperatives, and the not-for-profit sector, not to mention between countries. Unsurprisingly perhaps, considering their for-profit nature, private companies had the highest average number of staff (although they have the same median), while cooperatives on average had a little over half as many. The not-for-profit sector reports the lowest number of total staff, which may reflect their size and/or limited financing options, while their focus may also not be exclusively on producing RES. The public sector's sample size was too small to make a definitive observation. Initiatives from NL, UK, and ES (and to a certain extent IT) reported the highest average number of staff.

We also collected information on the financing strategies of the RES prosumer initiatives in our dataset, which we correlated with their legal form and country of origin. Most respondents indicated more than one form of financing. The top choice in terms of financing (Figure 6), whether correlated by country or by legal form, was through member contributions and/or the founders of the initiative (reflecting the high representation of cooperatives in our dataset). This was followed by public funding, whether regional, national, or from the EU, and then by bank loans, whether traditional or ethical/non-traditional. The latter was a financing form par excellence for those investing in (typically expensive) wind energy projects. More alternative forms of financing, such as collecting single donations from individual citizens and crowdfunding, tended to be residual choices, as reported by less than $10 \%$ of our dataset, while these forms of financing were completely absent from the German sample. Almost half of the initiatives stated that they had to borrow more than $€ 150,000$ to kick-start their initiative, with another significant number $(27 \%)$ claiming that they did not need to borrow 
any money. Most of the 'larger' investors were cooperatives, including all of the wind cooperatives, a few homeowner associations and other initiatives that invested in a heating system, and half of the Croatian companies. Among those that did not borrow any capital were most of the public institutions in our dataset, several local cooperatives, associations with a local focus (32 initiatives), and all the informal collectives.

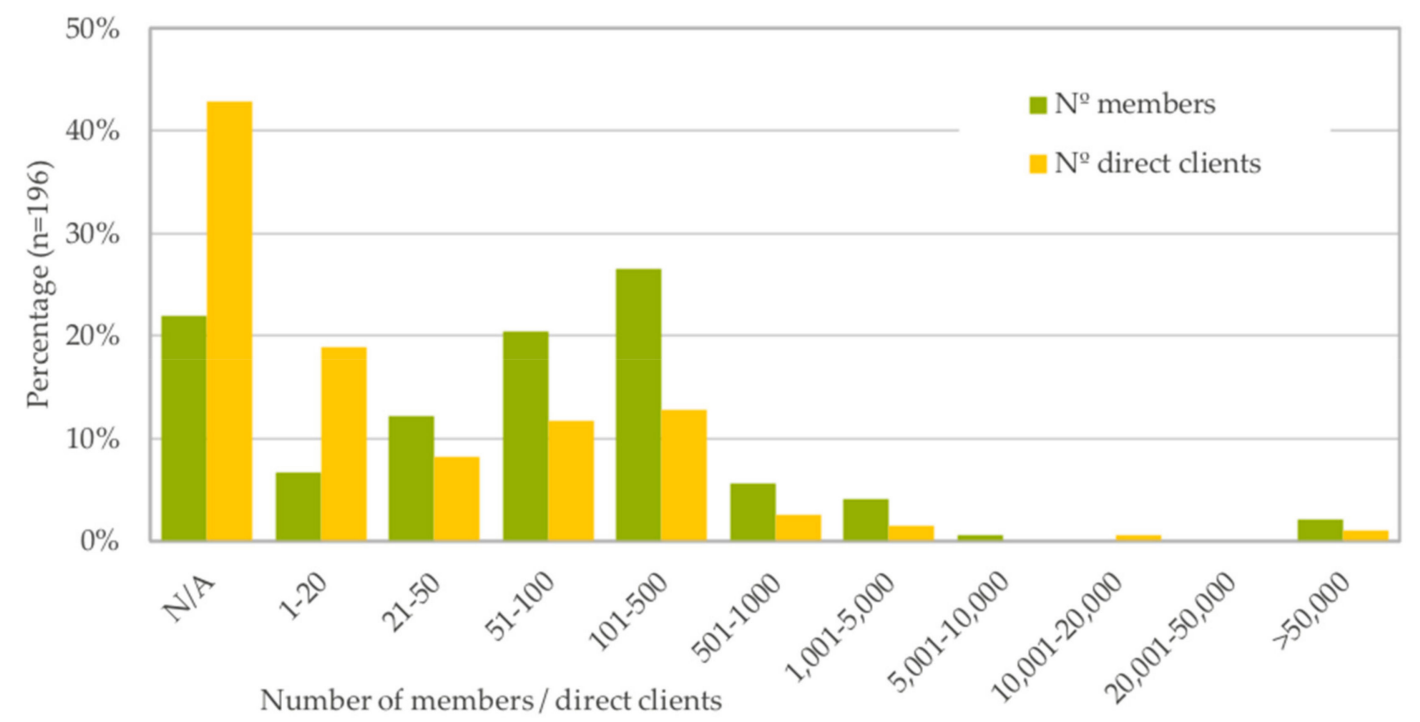

Figure 5. Number of members and/or direct clients of initiatives.

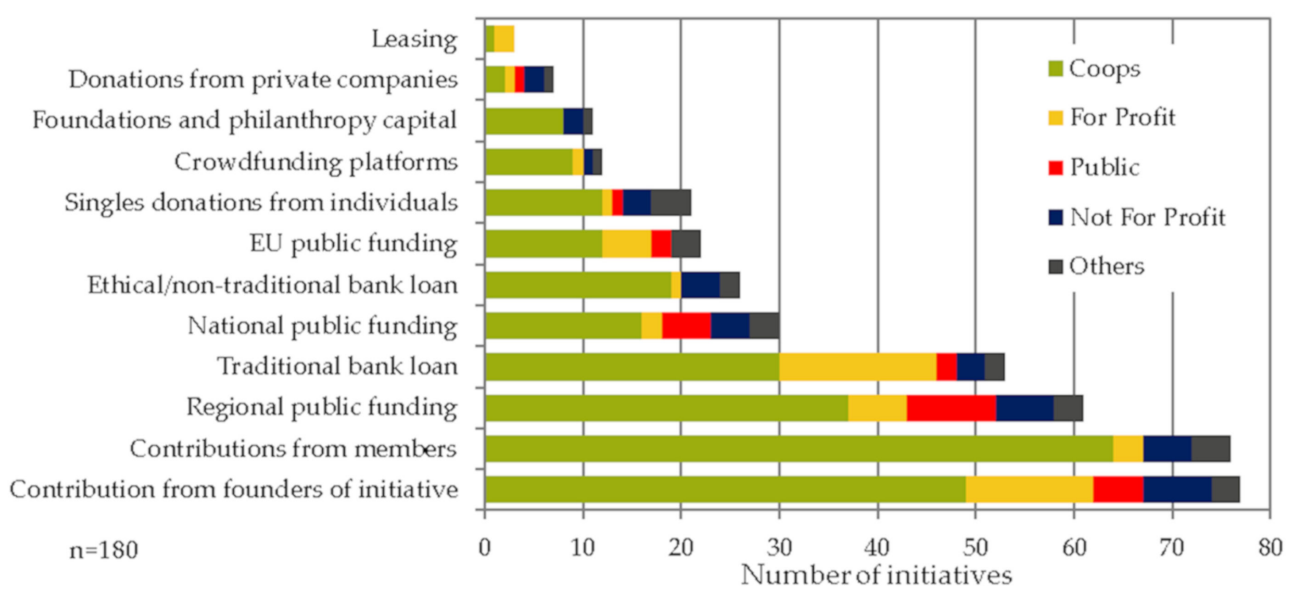

Figure 6. Financing strategies of the initiatives.

Regardless of the initial form of financing, two-thirds of the RES prosumer initiatives from our survey ended up owning their RES installation. In half of the remaining initiatives, the founding or supporting organisation owned the installation. This was the case of the initiatives founded by another cooperative or by an NGO, or that varied their partnerships according to each project (letting the partner own the equipment). The remaining options (such as co-owning with a utility or even the possibility of each member owning an installation) were very residual.

\subsection{Organisational Structure of Collective RES Prosumers}

As stated earlier, most of the initiatives with members in our dataset were mid-sized, with an average staff of 13 , and a median staff of eight, meaning that the teams responsible for running these operations are generally on the smaller side (146 initiatives had less than 15 people involved in running the initiative, and half of those that have members reported between 50-150 members). 
There was a significant gender imbalance in most of the surveyed initiatives, as illustrated by Figure 7. Most people working in the prosumer initiatives were male ( $72 \%$ overall), with the biggest imbalance found in German initiatives, where $80 \%$ of staff was reportedly male. Only in $17 \%$ of the 153 initiatives that answered these questions were there more women active in the initiative than men. Overall, these numbers resemble the gender distribution reported in the literature [44,45]. There were also three examples in the sample that were run by women only and 23 examples that were run by men only. The picture improves slightly when we move from management staff to non-management staff, especially in the public sector; however, on average, the change was only $\sim 10 \%$.

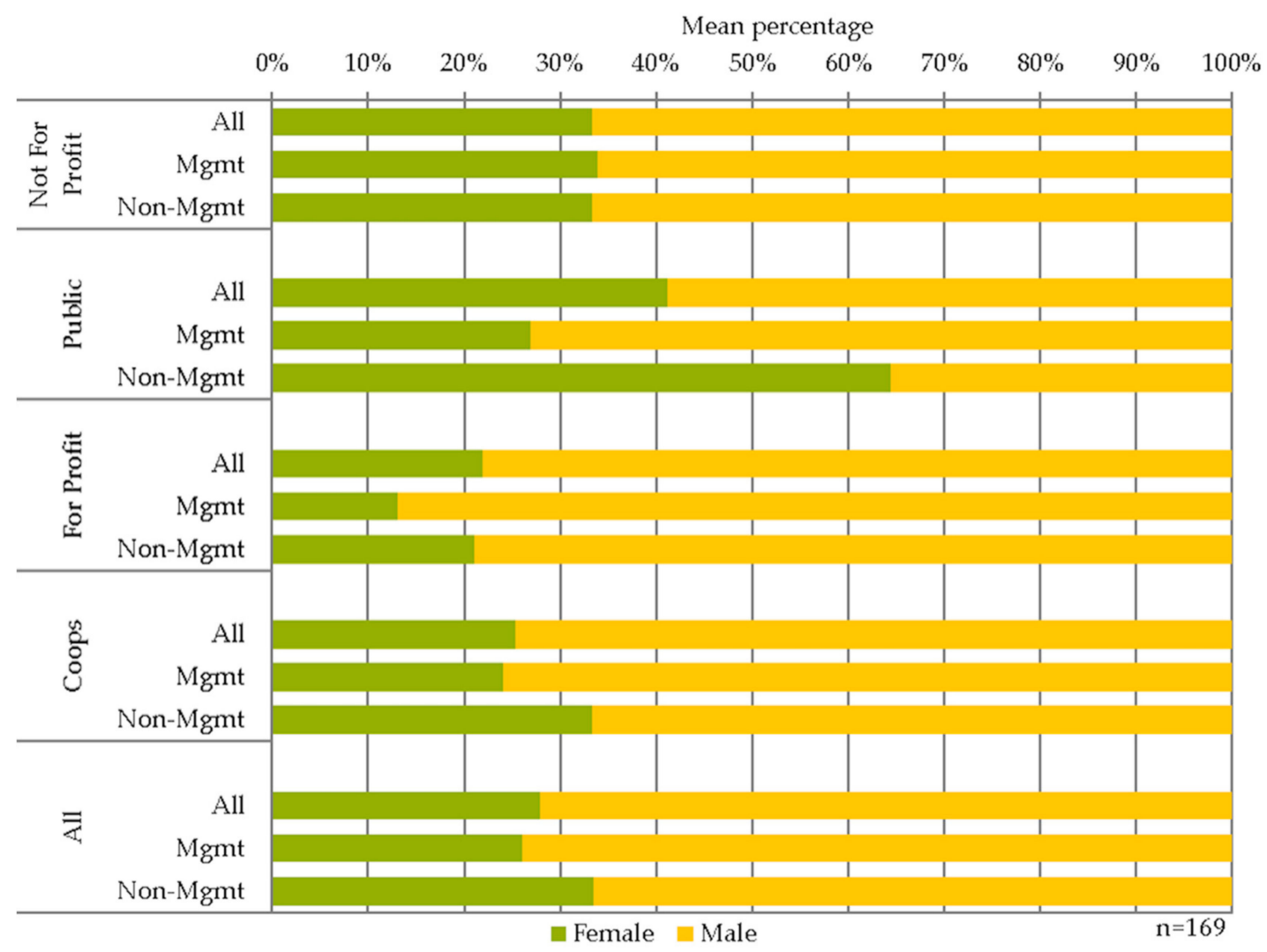

Figure 7. Balance of female vs male staff according to the type of position and top four legal forms.

The differences between legal forms and between countries when it comes to the balance between paid staff and volunteer staff were even more significant (Figure 8). On average, cooperatives depend on volunteers for more than two-thirds of their staff positions, the not-for-profit sector is almost exclusively dependent on volunteers ( $82 \%$ on average), whereas this balance inverts when we look at the other top legal forms. Looking at the different countries, we found that the Belgian and Dutch initiatives were the most dependent on volunteers ( $89 \%$ and $81 \%$, respectively), with German, UK, and French initiatives also showing a high dependence (between $72-75 \%$ ). The Spanish, Italian, and Croatian initiatives showed the opposite trend: they paid between $71 \%$ to $100 \%$ of their staff (Croatian initiatives reported $100 \%$, but as mentioned, these were practically all companies), while the Italian cooperatives had been in general established much earlier and often functioned as utilities for their region [19], which may explain their ability to pay their staff. The Spanish initiatives that responded to our survey were highly diverse, with no obvious factor explaining why these were outliers. We will discuss the implications of the dependence on volunteering in the next section. 


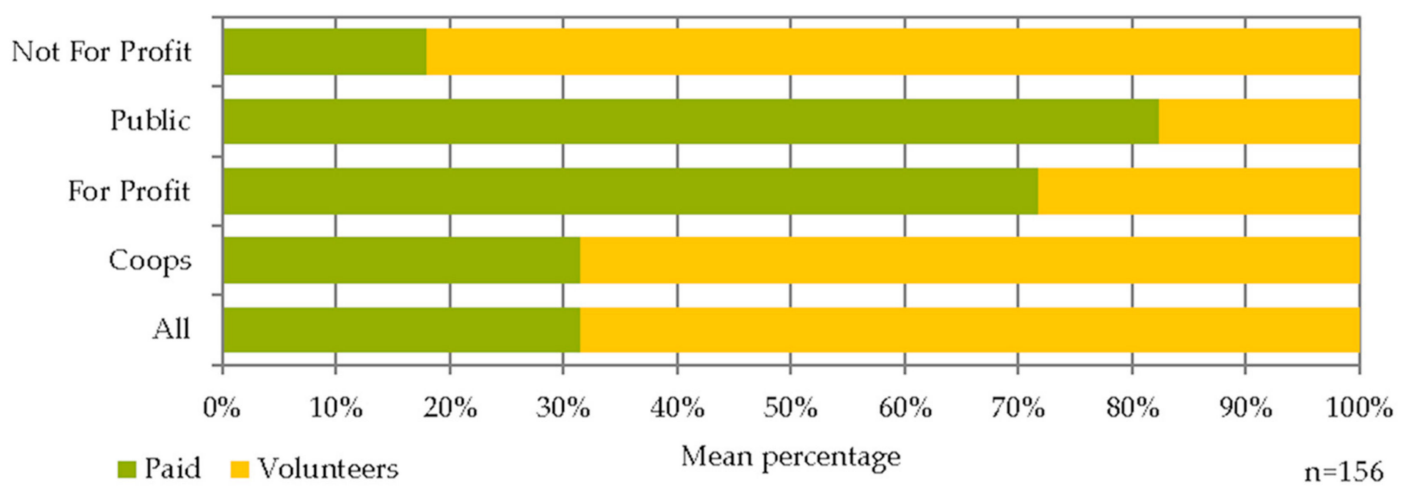

Figure 8. Balance of paid staff vs volunteers overall and for to the top four legal forms.

In terms of governance models, our survey measured how major (strategic) decisions were taken by the initiatives as an indicator of the degree of participation and inclusiveness [46]. Figure 9 presents the decision-making style at three levels of decision-making (founders, core team, and general assembly) as well as the level of involvement of staff in strategic decision-making, ranging from not informing staff, offering lip service to involvement (i.e., simply informing of decisions), asking for opinions, asking for actual input, and involvement in the discussion and analysis resulting in decisions, to fully including those that will be impacted or have the relevant experience in decision-making, and, finally, taking all strategic decisions together with all staff. We offered three forms of decision-making to choose from: majority vote, consensus, and consent, where we defined consensus as a decision on which everyone, without exception, agrees; whereas consent is a decision that not everyone may agree with but that all can live with.
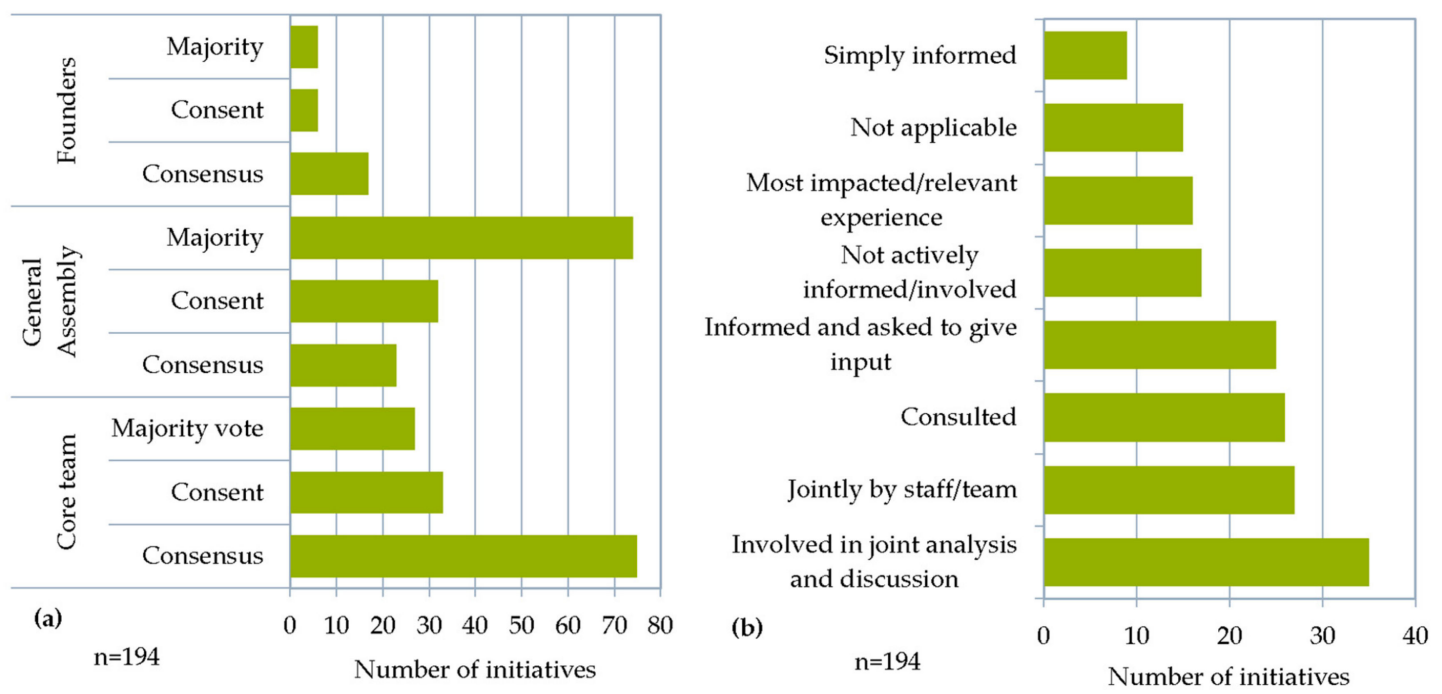

Figure 9. Strategic decision-making at the initiative: (a) at three levels of decision-making; (b) according to degree of involvement of staff.

About half of the cooperatives and not-for-profits reported that they decided by majority vote at the level of the general assembly. This is a common finding for the functioning of cooperatives and associations at this level, since they are legally obliged to hold at least one general assembly a year. About a quarter of cooperative and not-for-profit initiatives use the consent form of decision-making, with consensus (the most demanding form of decision-making) coming in last place. In contrast, the picture was inverted when it came to making important decisions at the level of the management team/core team and/or the founders. The favoured form here was decision-making by consensus (reported by 76 initiatives at the level of management), followed by a shared second place between consent and majority vote. These results point to issues of trust: in smaller, self-selected groups (i.e., founders, core 
teams), trust tends to be higher and consensus becomes a non-threatening decision-making tool to use. There were some relevant outliers, which could be further investigated: French initiatives on average reported that they did not use consensus in decision-making at the assembly level, whereas, in contrast, proportionally more of them opted for consent-based decision-making in the core team than the overall average. Other outliers were the initiatives from the UK, which tended to make major decisions primarily at the core-team level by consensus, and those from the Netherlands, where the use of consensus in assemblies was higher than that of consent (but still lower than the majority vote), compared to the overall average.

In terms of involving staff, the RES prosumer initiatives in our dataset clearly appear to favour the more participative/inclusive forms of decision-making. The top most participative forms of staff involvement were also the most reported by our respondents (close to $60 \%$ chose these). Importantly, most initiatives that reported the more participative forms of decision-making were cooperatives, thus staying true to the spirit of this organisational form. Of our 'big four' prosumer countries, only the UK initiatives deviated from the trend, converging on less participatory forms. The public sector initiatives, albeit a small sample, showed a clear trend in their answers: they either did not know if staff were involved, or stated that these were not informed. Since public sector organisations tend to follow stricter and multi-levelled hierarchies, this was not a surprising outcome.

Another measure we used to gauge inclusiveness in RES prosumer initiatives was the type of criteria for joining the initiative (Figure 10). The most popular answer was the absence of criteria for joining, followed by the need to be a local resident, and by the impossibility of joining (mostly the case of public institutions and companies). Although small in number (15), it is worth mentioning that some initiatives stated that a mandatory investment was their main criterium. This category would be larger if initiatives had not been forced to choose one answer option, since it is quite likely that most of the prosumer initiatives with members will require them to contribute upon joining. Finally, several initiatives made a point of mentioning that newcomers should agree with the initiative's principles and/or goals, highlighting a desire to create a sense of community. Again, the exact number could be higher if initiatives had not been forced to only choose one answer. The UK initiatives once again represented an outlier, with mandatory investment coming up as the second most important criterium, after 'no criteria'.

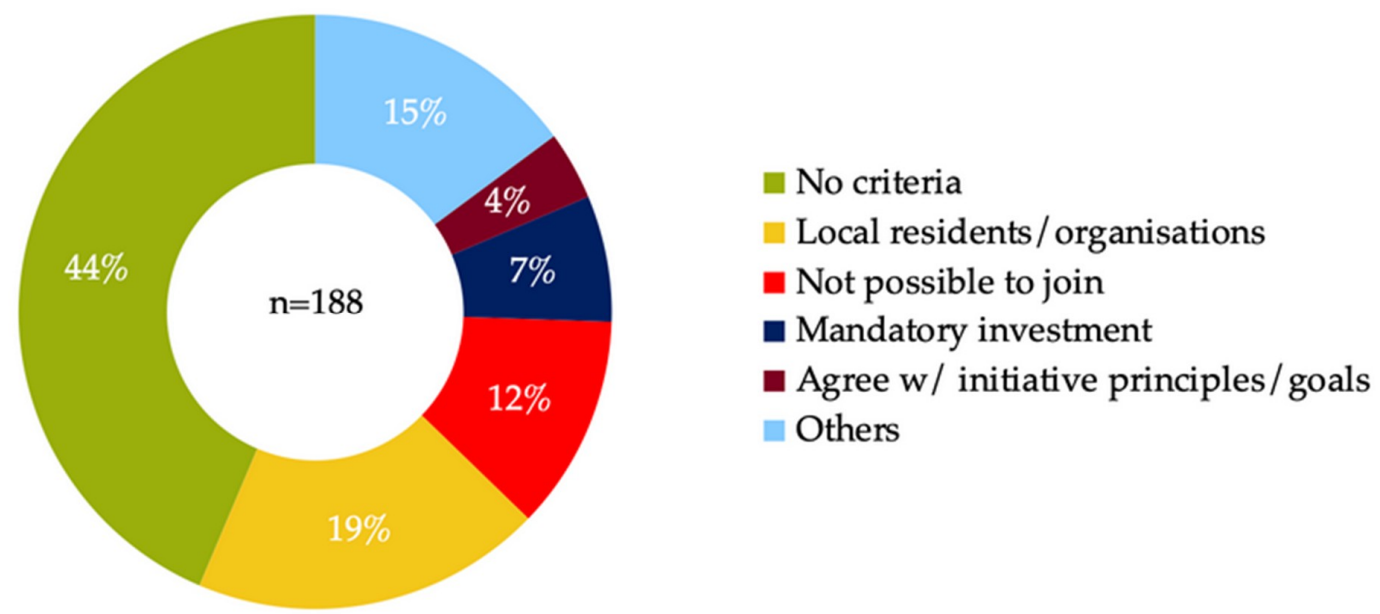

Figure 10. Criteria for joining the initiative.

We further asked respondents to indicate with which stakeholders (of a list of 15) they tended to collaborate and for what purposes (of a total of five types of relationships: 'knowledge sharing', 'self-promotion', 'access to funding', 'access to human resources', and 'access to material resources'). Their answers are shown in Figure 11 for the cooperatives, our largest sub-set, whereas answers for the top legal forms can be found in the Supplementary Materials (Document S2). Overall, the most popular stakeholder group with which prosumer initiatives engaged was that of communities/collectives and/or 
cooperatives for the purpose of knowledge sharing, followed by engagement with citizens/households for purposes of self-promotion, and finally, contact with civil society organisations and other prosumers, again for the purpose of knowledge sharing. All legal forms, except for public institutions, additionally showed an interest in engaging with local and regional government for the purpose of self-promotion. For-profit companies differed from other forms in that they engaged more with regional and national government for purposes of fund raising than any of the other forms of relationships. Public institutions slightly favoured self-promotion over knowledge sharing with citizens/households and civil society organisations, which is unsurprising considering their function is often to regulate and mediate, while outright cooperation with citizens and civic organisations is a more recent phenomenon. Nevertheless, although the sample was small, public institutions were the only legal form to almost equitably try to engage with all other stakeholders, reinforcing the idea of public authorities as mediators or hubs for energy transition. The for-profit sector also tended to favour self-promotion over knowledge sharing, a trait common to the business sector. Finally, all legal forms, except for the for-profit sector, showed considerable interest in engaging with national networks, interest organisations, or social movements. The opportunities mentioned by some respondents included the building of synergies between RES prosumerism and other climate-friendly activities, such as energy efficiency measures and awareness creation.

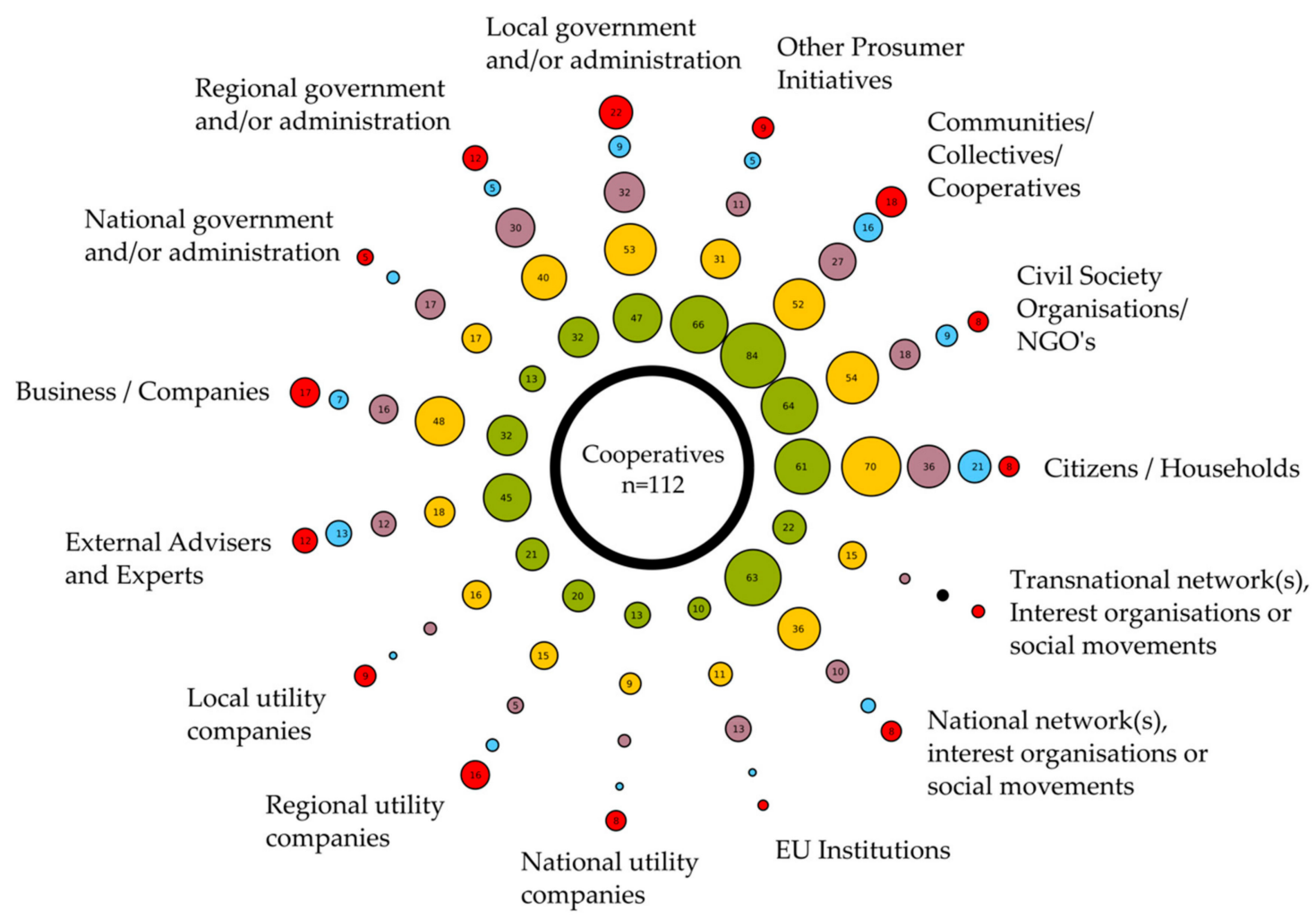

\section{Knowledge Sharing $O$ Promoting the Inititive $O$ Get Access to Funding Get Access to Human
Resources}

Figure 11. Key networking relationships cultivated by initiatives (please consult Document S2 for plots of top legal forms).

\subsection{Key Drivers and Perceived Hindering and Success Factors}

One of our main objectives was to understand the diversity of drivers behind the development of collective RES prosumer initiatives as well as hear from them what they perceive to be the key success factors and barriers to their development. 
We asked respondents to grade, on a Likert scale, the degree to which certain drivers motivated them to start the initiative (spider graph in Figure 12). The outcome was quite unequivocal. Over 60\% attributed the highest score to the driver 'tackling the climate change problem', followed by 'being part of the clean and low carbon transition', 'decentralising production', and finally the possibility to 'create a sense of community', closely followed by 'taking advantage of new RES technologies'. This overall trend was mirrored by the energy cooperatives in our dataset, except for the latter motivation, which was replaced by 'reducing the environmental impact of existing activities of the organisation/collective/community'. The for-profit sector appeared to be divided about their key motivation between 'responding to local demand/needs' and 'tackling the climate change problem', with the second place also divided, this time between 'being part of the low-carbon energy transition' and 'decentralising energy production'. The public sector differed from the previously mentioned legal forms by electing 'reducing the environmental impact of existing activities of the organisation/collective/community' as their second choice, while it did not appear to value 'creating a sense of community'. Finally, the not-for-profit sector placed 'reducing energy costs' in second place, before 'being part of the clean and low carbon transition', and relegated 'decentralising production' to fifth place.

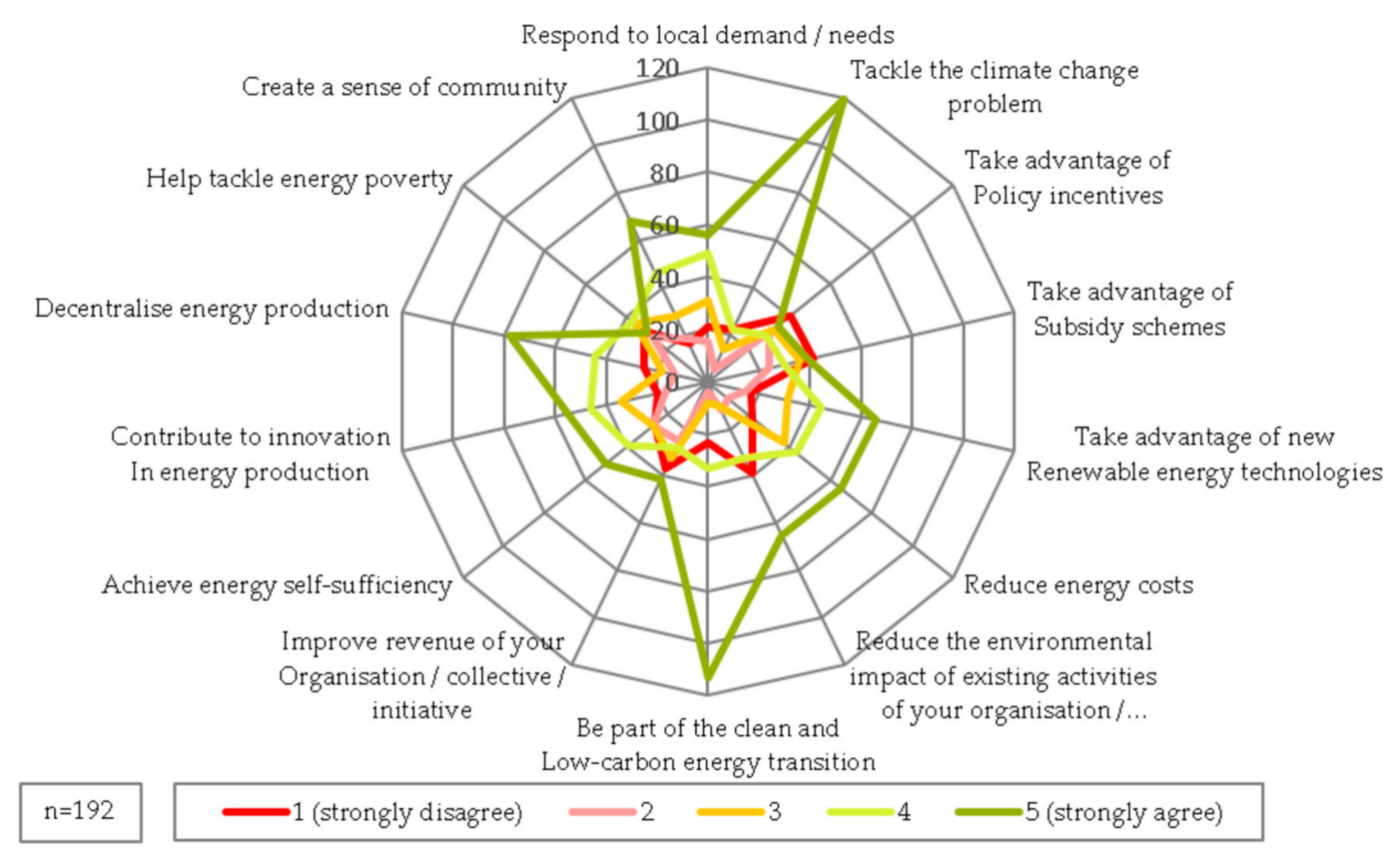

Figure 12. Main reasons for starting a prosumer initiative.

As an indirect measure of motivation, we asked RES prosumer initiatives about any additional services they might offer (Figure 13) and obtained mixed results. A third of initiatives focussed exclusively on self-production and consumption, and offered no other services. About half of these were cooperatives, while the other half was made up of public institutions, some smaller associations, and two of the Croatian aggregator companies. When additional services were offered, energy efficiency advice took first place, followed by community-focussed services, such as community organising. Energy storage appeared here as an upcoming technology as much as an additional service, with several initiatives contemplating offering this service in the near future. 


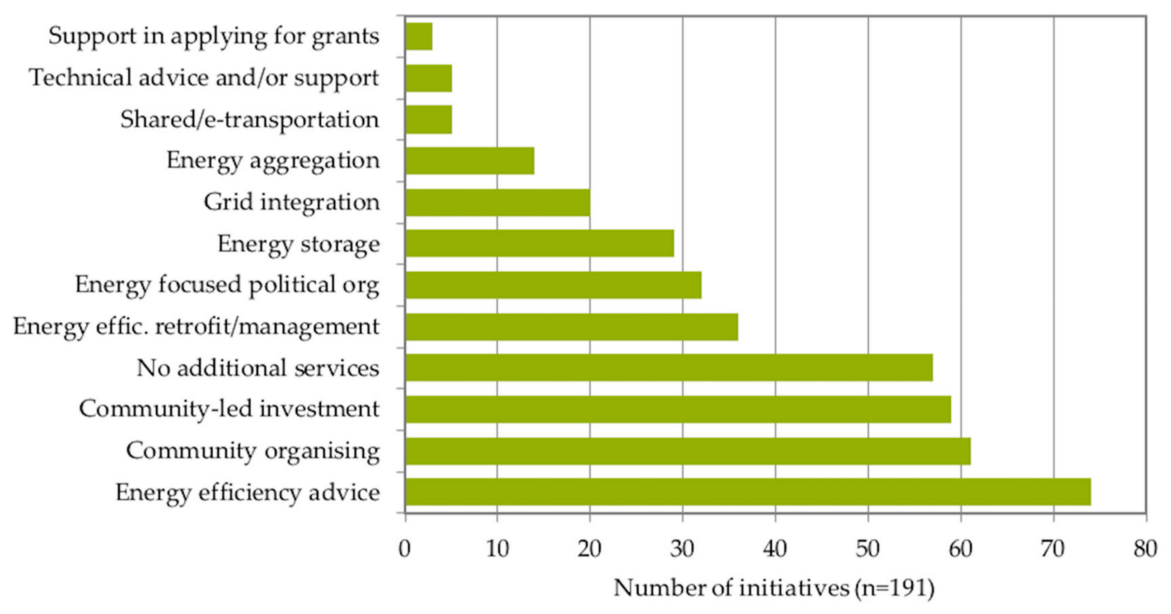

Figure 13. Additional services offered by prosumer initiatives.

Besides the key drivers, the key facilitating and hindering factors as perceived by our respondents were among our most elucidating results. Respondents were asked to choose the top three factors that most facilitated as well as those that most slowed down the development of their initiative, in their opinion. The results are presented in the spider graph in Figure 14 below.

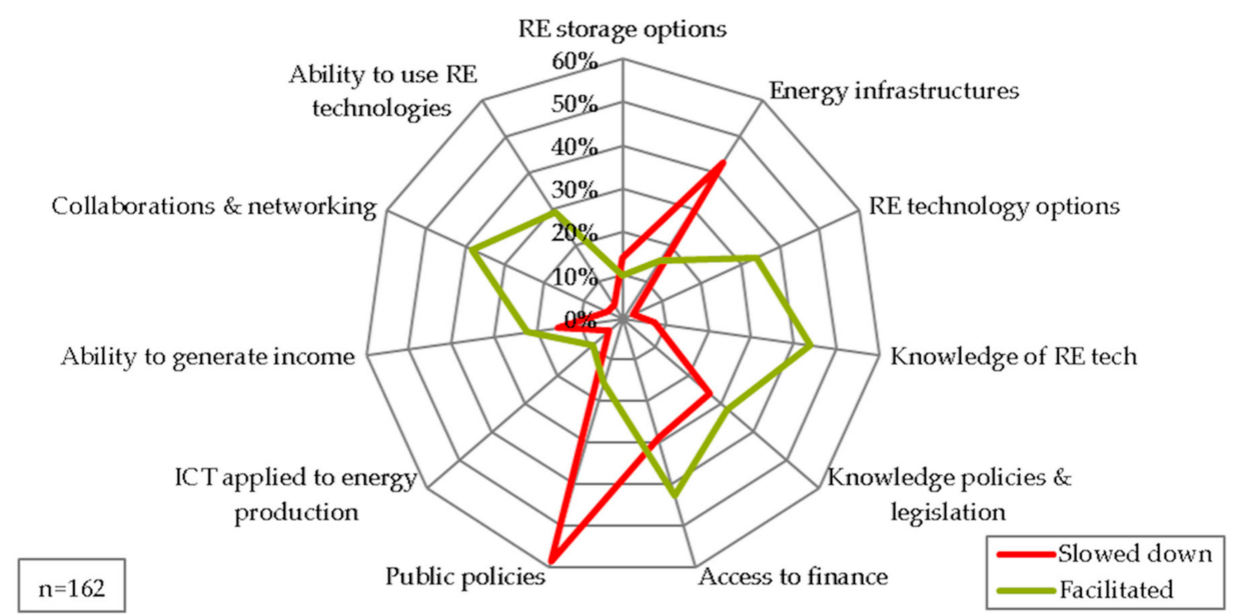

Figure 14. Main hindering (slowing down) and facilitating factors for the development of a prosumer initiative.

We found that the top four factors perceived as most facilitating by our respondents were:

- Knowledge of renewable energy technologies.

- Access to finance, subsidies or grants.

- Collaborating and networking with others.

- Renewable energy technology options available.

These factors were consistent across the countries as well as the legal forms, except for initiatives in France and other countries newer to RES prosumerism (PT, ES). These tended to rank the factor of 'ability to use RES technology' above that of 'renewable energy technology options available'.

The top four factors perceived as most hindering by our survey respondents were:

- Public policies and legislation for renewable energy initiatives.

- $\quad$ Energy infrastructures (e.g., grid, meter).

- Access to finance, subsidies, or grants.

- Knowledge of policies and legislation in RES production. 
These 'negative' factors were equally consistent across the countries as well as the legal forms. Curiously, there were a couple of factors that received a high classification in both categories, meaning that, depending on whether the initiative can harness the factor in question, it will be either a facilitating factor or a barrier. Such is the case for 'access to finance, subsidies or grants', which is considered to be critical to the initiative's development as well as a contributor to its potential failure. This was also true for 'knowledge of policies and legislation in RES production', which was considered as important for both the successful development (rated in fifth place) as for its failure when absent. It is illustrative of the importance of networking that the socio-political factor of 'collaborating and networking with others' was deemed as important as having the appropriate RES technology.

Several specific complaints were volunteered by respondents from different countries. German, Dutch, and Belgian respondents complained about complex bureaucracies amidst inconsistent laws and rules, and about the contradictory attitudes of authorities at different levels (regional vs national). French initiatives complained that they were not allowed to consume what they produced, while UK initiatives expressed their apprehension about the end of FiT. In smaller countries such as the Netherlands and Belgium, a lack of space for RES installations was reported as another barrier.

\section{Discussion}

Taking stock of the survey results and comparing them to our review of the context for RES prosumerism, we found that true collective prosumers (in the sense of simultaneous self-production and -consumption in a collective context) were hard to find. In some countries, of which France is an example, energy may be produced and sold, but not self-consumed. In other countries (Croatia and Germany), it is quite easy to self-consume, but very hard to sell (a license is needed). The nine countries under study, as explained in detail in [10], varied significantly as to whether they recognised energy communities, allowed neighbours in the same building or apartment block to self-consume collectively, allowed energy communities to share electricity among members, or whether a supplier license was needed, to name but a few legislative features.

Our results open up several avenues for future research. Concerning legal forms, given the variety of forms that prosumer initiatives can choose from (see Table 3), we were expecting to find a high number of energy cooperatives, a legal form that allows for the hybridisation of socio-ecological objectives and the ability to make profit as well as share the latter among 'shareholders' (i.e., the members of the cooperatives). We were not expecting to find so many other hybrid forms such as public-private partnerships, other formal and informal partnerships, and the choice of the Ltd. or associative form to represent energy communities, which the EC so far does not recognise as a legal entity in itself (see Clean Energy Package Directives [3,5]). The occurrence and implications of hybrid organisational forms in the field of energy, particularly the cases of energy cooperatives and social enterprises, is becoming a topic in itself, and has been discussed by a number of researchers: Raven [47], Huybrechts and Haugh [8], and Bauwens et al. [48]. Although the cooperative form appears to offer initiatives that identify as energy communities a satisfying legal entity, it is also patent in our survey results that this choice is not always possible or ideal. In the Netherlands, to qualify for the so-called 'PostCodeRoos' incentive, you need to be a cooperative, whereas in France, you can run a for-profit organisation such as a SAS (Société par actions simplifiée) as a cooperative, reaping benefits from both organisational forms. More qualitative or in-depth research among RES prosumer initiatives operating under different legal forms may explain better what is happening.

As for the energy needs addressed by RES prosumer initiatives, electricity clearly stands out. Factors influencing the choice of energy needs that prosumer initiatives wish to address still require further research. Among these are the fact that many RES subsidies are for electricity production and that RES electricity is easier to share collectively, whereas a heating system requires very specific conditions (e.g., the need to refit entire blocks, neighbourhoods, or districts, a higher entry barrier, a significant change in basic grid infrastructure). 
Although we showed earlier (in Section 2) that official country numbers for the shares of renewable energy in gross final energy consumption maintain wind energy as the leading RES technology, the trend encountered in our results-with photovoltaic PV leading the RES technology choices-may be explained by the fact that the growth of wind energy has occurred largely independently from prosumerism, with projects mostly developed by energy companies [49]. Additionally, wind energy projects are very costly [31]. On the other hand, solar-powered technology is growing fast, and it has proven easier to build and set up. It is therefore expected to take the lead from wind energy in the upcoming years [50].

Gender is without a doubt an important crosscutting topic for research on RES prosumers. The extremely low overall involvement of women in energy initiatives has already been mentioned in a number of studies and reviews [34,35]. Some explanations for this, in the case of Germany, can be found in [44], whereas French data indicate that gender differences are not just linked to individual preferences and investment attitudes, but also significantly influenced by cultural, social, and political factors [33]. There were interesting country differences regarding the gender balance between our initiatives. Whereas the average percentage of women in the initiatives in our dataset did not exceed $30 \%$, Portuguese and Spanish initiatives reported on average close to 50\% women in management positions, and $60 \%$ in non-management positions. Spain and Portugal happen to be countries that have been flagged for low levels of overall volunteer participation, which is why, despite the small sample size for these countries, finding more female than male volunteers merits further investigation [51]. Between the legal forms, no significant differences can be reported as to the female/male balance, apart from the public sector, the only type of organisation with high numbers of female staff, albeit mostly in non-management positions.

Regarding the financing choices of our respondents, we found that most of those that did not borrow any capital were public institutions, aside from several local cooperatives, associations with a local focus (32 initiatives), and all of the informal collectives. These patterns closely resembled those obtained for community energy in Germany [52]. Kahla, for instance, reported an 'inverted leverage effect' that has been observed for social enterprises in general: high equity ratios may be explained by lower costs of equity for some initiatives compared with costs of debt (for more also see $[53,54])$. Another observation that we can make is that the United Kingdom, one of the countries with the broadest mix of financing in our dataset, is also the country with the least initiatives opting for a traditional bank loan (9\%), whereas Germany and France have quite a high share (46 and 78\%, respectively), reflecting different banking cultures and/or systems in these countries. UK initiatives appeared on average to be more professional and better financed, but the recent abolishment of the Feed-in-Tariff may turn this panorama upside down [23].

The extreme dependence of cooperatives on volunteer labour constitutes one of their key weaknesses, as reported by our respondents: one representative from a Dutch cooperative put it this way: 'We need to move from hobby to lobby, from volunteer organisation to professionalisation' (translated from the original Dutch). This fragility is also something Brummer discusses in his comparative review of community energy in the USA, UK, and Germany [30]. He found that a reliance on volunteers was a barrier in the USA and Germany, but not in the UK. Although volunteers are generally highly motivated, their lack of expertise in certain areas, and possible limitations in terms of dedication, means that cooperatives and energy communities will need to spend money on qualified consultants. Research on non-profit organisations highlights professionalisation as a stage of development in the life-cycle of non-profits [55,56], which respond to external pressures—'isomorphism' [57]—or rely on government grants and trading [58,59]. As a reaction, non-profits have taken different paths [60]. However, research into not-for-profit organisations also documents some flipsides of professionalisation: the danger of 'mission drift', less engagement by volunteers, or diminishing capacity of social capital production [61-63]. In part, these negative effects seem to rest on whether members or external staff are employed [59-61]. Against this background, current EU policy and transposition of directives into national law may create space for the professionalisation of some collective prosumer initiatives, 
but will most probably also lead to hybridisation and organisational differentiation in this subsector. The heavy reliance on volunteers in the largest sub-sector of collective RES prosumerism may constitute an underappreciated barrier that current EU policy is not addressing.

Our study confirmed the predominance of social drivers over financial and more inward-focussed motivations for collective forms of RES prosumer initiatives. Over $60 \%$ of respondents attributed the highest importance to tackling the climate change problem and being part of the clean and low carbon transition, while about half also attached importance to the decentralisation of production and to creating a sense of community. While the nuanced differences in terms of motivation found in the for-profit sector and public institutions can be explained by their respective missions (see Section 4.4.), it remains unexplained —-but does not speak to a favourable policy landscape-why over $20 \%$ of all legal forms, except for the for-profit sector, had a surprisingly negative view of the possibility of 'taking advantage of policy incentives' or 'subsidy schemes'. Whether this is a result of the difficulty in obtaining said support or whether they find this an unsound reason to start an initiative, is not clear. In contrast, the Croatian initiatives gave high scores to taking advantage of policy incentives as well as subsidy schemes, while 'reducing energy costs' and 'improving revenues of their organisation' also received high votes. Since the legislation in Croatia favours larger, profit-oriented set-ups [10], there is a lack of incentive and support for other forms of prosumer initiatives, particularly more decentralised ones.

Among our strongest findings was the perceived hindering vs facilitating factors reported by our dataset. Consistent across countries as well as legal forms (with the exception of France and recent prosumer countries such as Portugal and Spain, which were more concerned with the ability to be able to use RES technology), we found that initiatives listed as their top four facilitating factors the knowledge of renewable energy technologies, access to finance/subsidies/grants, collaborating and networking with others, and the availability of renewable energy technology options. However, initiatives in our survey felt that having good RES technology options was not sufficient if relevant energy infrastructures were not in place. In an overwhelming first place, existing public policies and legislation for RES initiatives were perceived as a key barrier. This reinforces our findings that the fact that legislation in the surveyed nine countries is currently either being revised, or likely to be revised after the new EU directives come into effect, creates an unstable and uncertain environment for RES prosumerism to flourish. Around $60 \%$ of our respondents signalled RES public policies and legislation as the top hindering factor to their development. Indicative of a potential crucial barrier to prosumerism development, access to finance appears as both a facilitating and a hindering factor. Furthermore, the importance attributed to collaboration speaks to its multi-functional aspect, allowing initiatives to join others (strength in numbers), learn from others as well as learn together, promote themselves and their common cause, and share resources. Cooperation of different sorts allows the prosumer initiatives to build up know-how beyond what they would have achieved alone, a function that has also been observed for cooperation among municipal utilities [64,65]. Free knowledge sharing and the use of open source tools are characteristic of the cooperation between collectives that do not have profit as their primary objective, and can jumpstart collaborative economies.

Finally, the initiatives in our dataset showed considerable interest in engaging with national networks, interest organisations, or social movements, a finding that illuminates patterns of cooperation in a sub-sector that shares some similarities with the ones found among (local) municipal utilities [66].

\section{Conclusions}

This paper examined a wide spectrum of collective prosumers beyond the better-known forms of energy cooperatives. The aim was to establish the current state of play for collective forms of RES prosumerism in Europe considering the demands and promises of the Energy Union. Our documentary review and survey across nine EU countries revealed key differences, challenges, and needs across different types of collective prosumers and across national contexts, and can therefore inform the design of an incentive system supporting clean, fair, and sustainable energy transition pathways. Our research established a comprehensive baseline and a broad cross-section of the diverse profiles 
of the RES prosumer energy actors, raising several red flags, such as the persistence of an uncertain political and legislative setting; the challenges of volunteer-run structures; the lack of tailor-made policies for collective RES prosumer initiatives-namely those with a civic focus; slow progress in terms of the democratisation of critical energy infrastructures-in particular, the digital infrastructure; the difficulties of accessing finance for RES prosumer initiatives; and the need to more widely share knowledge of RES technology options as well as of how to implement and run RES installations. It also pointed out opportunities and new pathways including the chance to create synergies between RES prosumerism and other climate friendly activities (e.g., complementing prosumerism with energy efficiency measures or awareness creation); the possibility to improve collaborations and knowledge-building between different stakeholders; or the ability for RES prosumers to also become energy suppliers.

Based on these results, we highlight in the following a number of dilemmas for RES prosumer collectives and provide recommendations for national legislators in the transposition of EU directives as well as for future research.

The first dilemma relates to the way the collectives are internally organised: two main types can be distinguished, those collectives relying on volunteer work and thus civic activism, and those relying on paid staff and thus a more commercial and/or bureaucratic attitude. With regard to making energy transitions more inclusive, the-on the surface more accessible - civic activism holds a risk of exclusion as it means that only those who have the time and resources can afford to volunteer. A related concern in this dilemma is the chronic under-representation of women in energy initiatives.

The second dilemma relates to the choice of an appropriate legal form/organisational structure for a RES prosumer initiative: this is a less straightforward choice than one would expect since it is tied to a number of conditions and factors, such as the availability of different legal forms in different countries, or how specific legal forms are tied to specific support and subsidy schemes, and whether there is an obligation to apply for a production license. The reality of legal forms leads to potential conflicts when it presupposes a certain value orientation (such as a for-profit orientation), while the collective may be aspiring to combine such for-profit goals with social goals and thus a more civic-oriented role in the energy transition.

A third dilemma relates to the further formalisation of prosumer initiatives through the advent of the Clean Energy Package. While this promises clarity and support, it also forces such initiatives to formalise. The fact that the newly coined EU concepts for collective RES prosumers-'renewable energy community' and 'jointly acting renewables self-consumers'-imply that the collective must choose one or other legal form to run the community rather than being able to register as such, could limit rather than stimulate the expansion of the more civic-inspired prosumer initiatives. Informal groups or partnerships will not be able to qualify as an energy community. With this limitation comes the risk of hindering the decentralisation of the energy system and the uptake of RES. It is now up to national governments to pick up this challenge as they implement the new EU Directives, a challenge that implies more diverse interpretations and treatment of prosumers of different types in different EU countries, to the benefit of an inclusive, clean, fair, democratic, but also rapid energy transition.

We propose several recommendations for policy-makers from Member States involved in the transposition of the Directives from the Clean Energy package:

- Develop supporting legal and institutional frameworks for collective forms of RES prosumerism that recognise and support a range of organisational forms;

- Work with national regulators and network operators to ensure fair, open, and transparent access for prosumers to the electricity network infrastructure;

- Develop long-term and consistent approaches to financial support for prosumerism, avoiding cliff edges and uncertainty;

- Harness local and bottom-up solutions to solve energy system challenges, recognising the social/non-financial value that is created by these solutions; 
- Ensure and support fair, open, and inclusive participation in the prosumer energy transition; especially for marginalised groups, such as women, ethnic minorities, and those with limited material resources.

Within the methodological limitations of a survey study, we have achieved a broad range of cross-cutting aspects of the collective forms of RES prosumers and provided a baseline overview of 'what is'. Now, ongoing and future avenues of research can build on these exploratory findings and examine them more in-depth, across different types of prosumer collectives as well as across cultures and countries in Europe. The most relevant avenues to further explore, in our view, are:

- The implications and policy recommendations stemming from the mismatch between an initiative's legal/organisational form and its mission;

- The key factors driving renewable energy technology needs and choices;

- The reasons behind and fixes for the differences in female/male balance in terms of participation;

- The challenges and fragilities of volunteer-run organisations, and how to overcome these;

- The significance of different internal decision-making and governance styles as well as viable business and financing models that support RES prosumerism.

Supplementary Materials: The following are available online at http://www.mdpi.com/1996-1073/13/2/421/s1, Document S1: Survey form 'New Energy for Europe'; Document S2: Key networking relationships for key RES prosumer legal forms.

Author Contributions: Conceptualisation, L.H. (Lanka Horstink), J.M.W., K.N. and I.C.; methodology: L.H. (Lanka Horstink), J.M.W., K.N., G.P.L., E.M.-G., S.G., I.C. and L.H. (Lars Holstenkamp); software, G.P.L.; validation, E.M.-G., S.G. and G.P.L.; formal analysis, E.M.-G., G.P.L., S.G. and L.H. (Lanka Horstink); investigation, L.H. (Lanka Horstink), J.M.W., G.P.L., E.M.-G., S.G., I.C., S.O., D.B. and K.N.; data curation, E.M.-G., S.G. and G.P.L.; writing-original draft preparation, L.H. (Lanka Horstink), and J.M.W.; writing-review and editing, J.M.W., K.N., I.C., S.O., L.H. (Lars Holstenkamp), E.M.-G., S.G. and D.B.; visualisation, E.M.-G., S.G. and G.P.L.; supervision, K.N., L.H. (Lanka Horstink); project administration, I.C. and L.H. (Lanka Horstink). All authors have read and agreed to the published version of the manuscript.

Funding: The research leading to the results presented in this article has received funding from the European Union's Horizon 2020 research and innovation programme under grant agreement $\mathrm{N}^{\mathrm{o}} 764056$. K.N. was supported by the Fundação para a Ciência e a Tecnologia (FCT) postdoctoral fellowship grant (SFRH/BPD/120394/2016).

Acknowledgments: The authors wish to thank the following researchers for their contribution to the data collection and to the discussion that formed the basis of the present analysis: Mark Soares (UPORTO); Jeremie Fosse (ECO-UNION); Kristian Petrick (ECO-UNION); Mireia Reus (ECO-UNION); Thijs Scholten (CE DELFT); Bettina Kampman (CE DELFT); Mark Davis (ULeeds); Stephen Hall (ULeeds); Arthur Hinsch (ICLEI); Marta Toporek (CLIENTEARTH); Michele Zuin (ICLEI); Moritz Ehrtmann (LEUPHANA); Tomislav Novosel (UNIZAG); Tomislav Puksec (UNIZAG); and Ana Lovrak (UNIZAG).

Conflicts of Interest: The authors declare no conflicts of interest. The funders had no role in the design of the study; in the collection, analyses, or interpretation of data; in the writing of the manuscript; or in the decision to publish the results.

\section{Appendix A}

Table A1. Survey questionnaire: distribution of questions according to category. Adapted from: [23] (pp. 56-57).

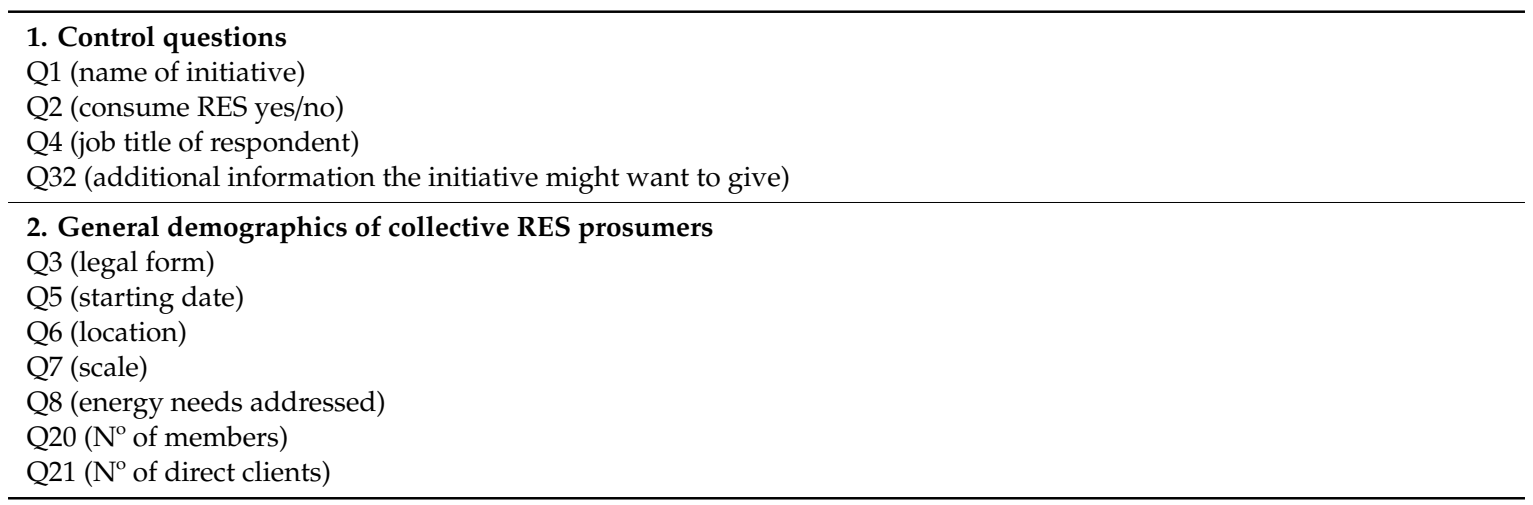


Table A1. Cont.

3. Use of technology by collective RES prosumers

Q9a (which technologies are used or planned)

Q9b (installed capacity of these technologies)

Q10 (is the initiative connected to the grid)

Q11 (when did they start producing/plan producing)

Q12 (energy produced in 2017 for each technology)

\section{Governance/organisation of collective RES prosumers}

Q15-19 (staff characteristics: total number, women/men proportion, volunteer/paid staff proportion)

Q26 (decision-making style in executive organs)

Q27 (involvement/participation of staff/non-management teams in decision-making)

Q28 (networking, openness to others)

\section{Financing of the initiative}

Q22 (who owns the RES equipment)

Q23 (how are initiative activities financed)

Q24 (how much capital was borrowed, if any)

Q25 (what are the 4 largest income generators)

\section{Motivation/ambition of the initiative}

Q13 (whom is energy produced for?)

Q14 (any additional services that are offered)

Q30 (Likert scale (1-5) of reasons to start the initiative)

7. Hindering and facilitating factors as perceived by collective RES prosumers

Q31 (which 3 factors have most slowed down and which 3 factors have most facilitated the development of the initiative)

\section{Appendix B}

Excerpts from the survey form for collective RES prosumers.

\section{PROSEU SURVEY}

New Energy for Europe: Renewable Energy Prosumer initiatives

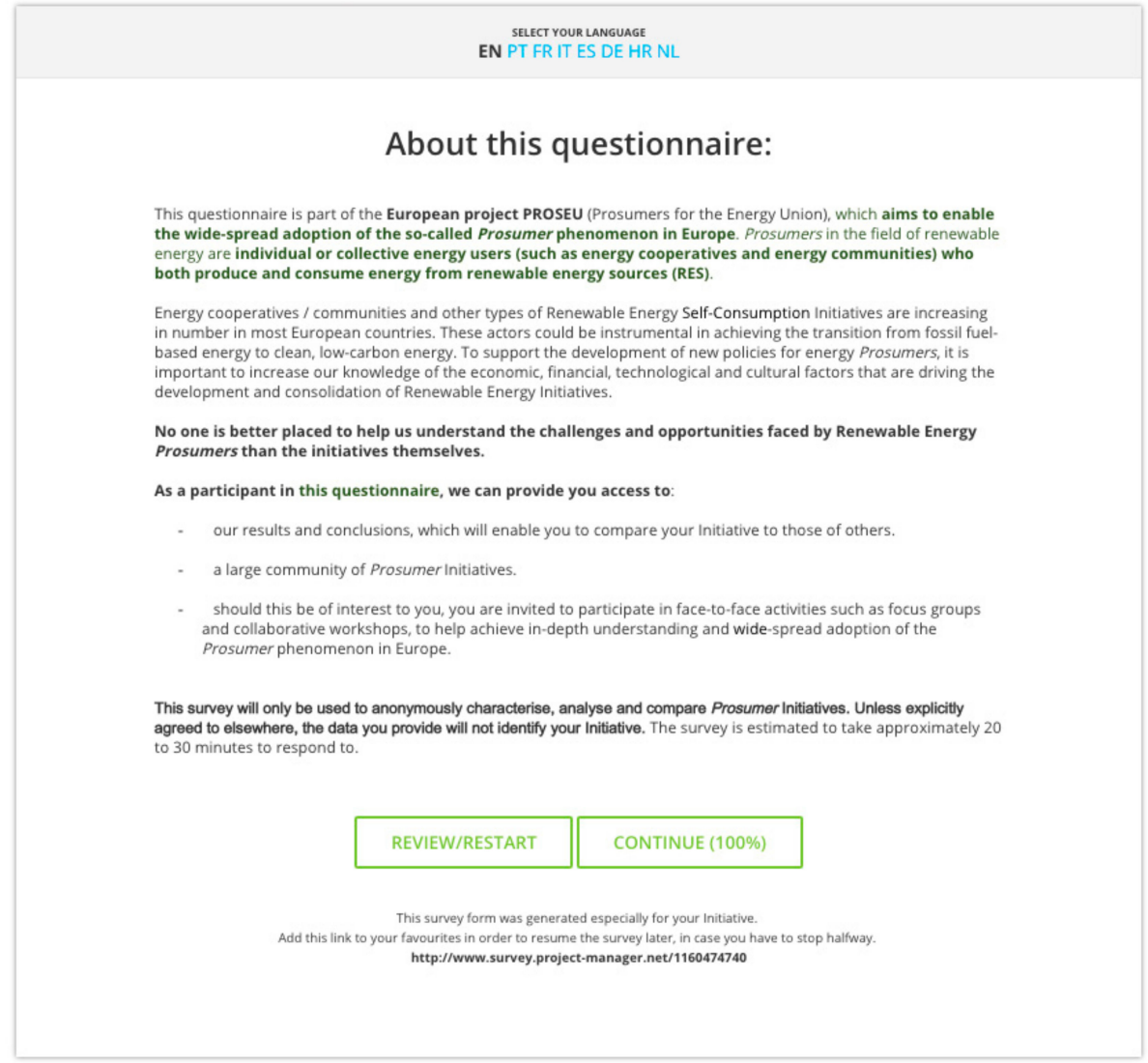

Figure A1. Front page of the survey form. 


\section{PROSEU SURVEY}

New Energy for Europe: Renewable Energy Prosumer initiatives

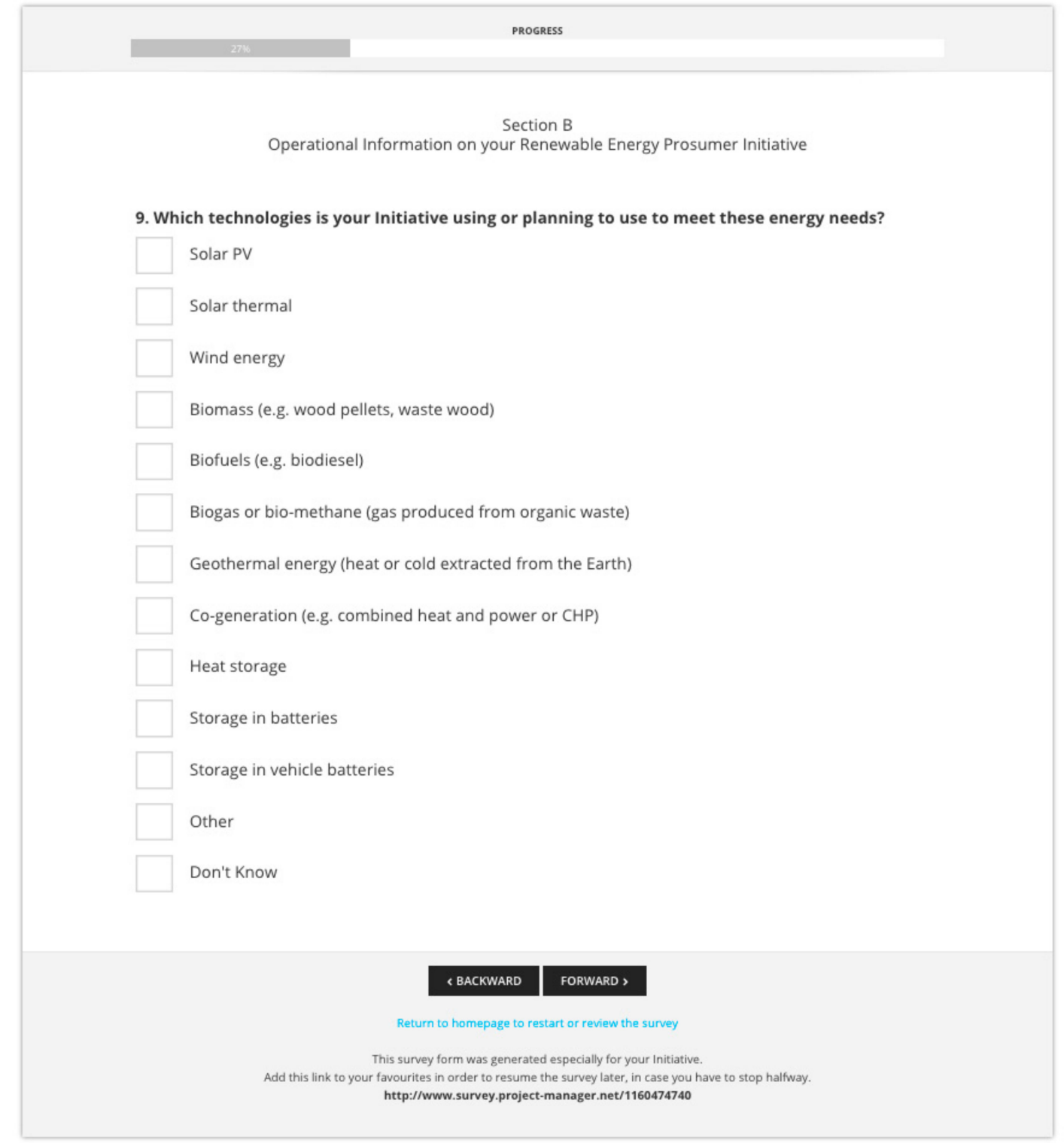

Figure A2. Question 9 of the survey form. 


\section{PROSEU SURVEY}

New Energy for Europe: Renewable Energy Prosumer initiatives

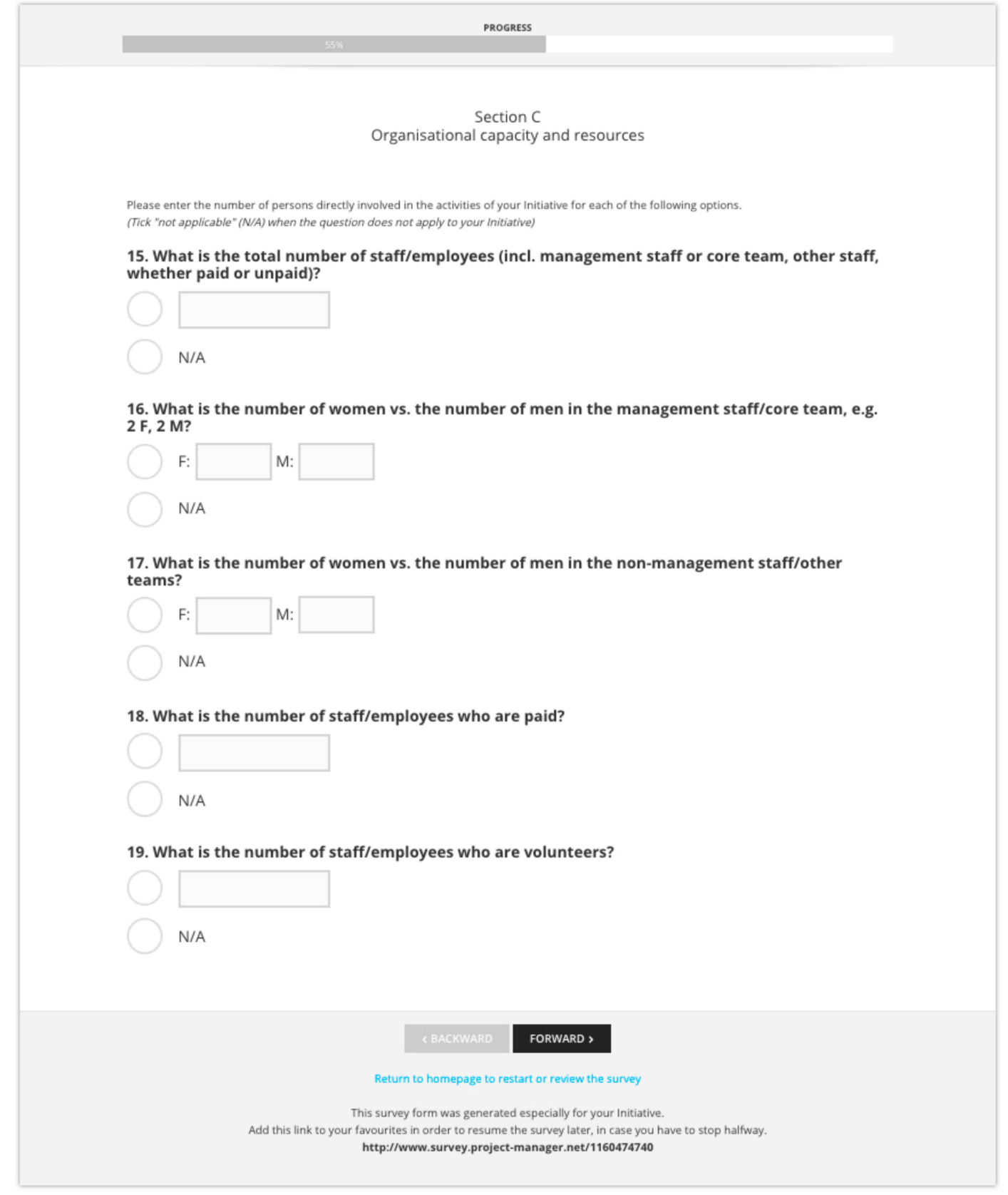

Figure A3. Questions 15-19 of the survey form. 


\section{PROSEU SURVEY}

New Energy for Europe: Renewable Energy Prosumer initiatives

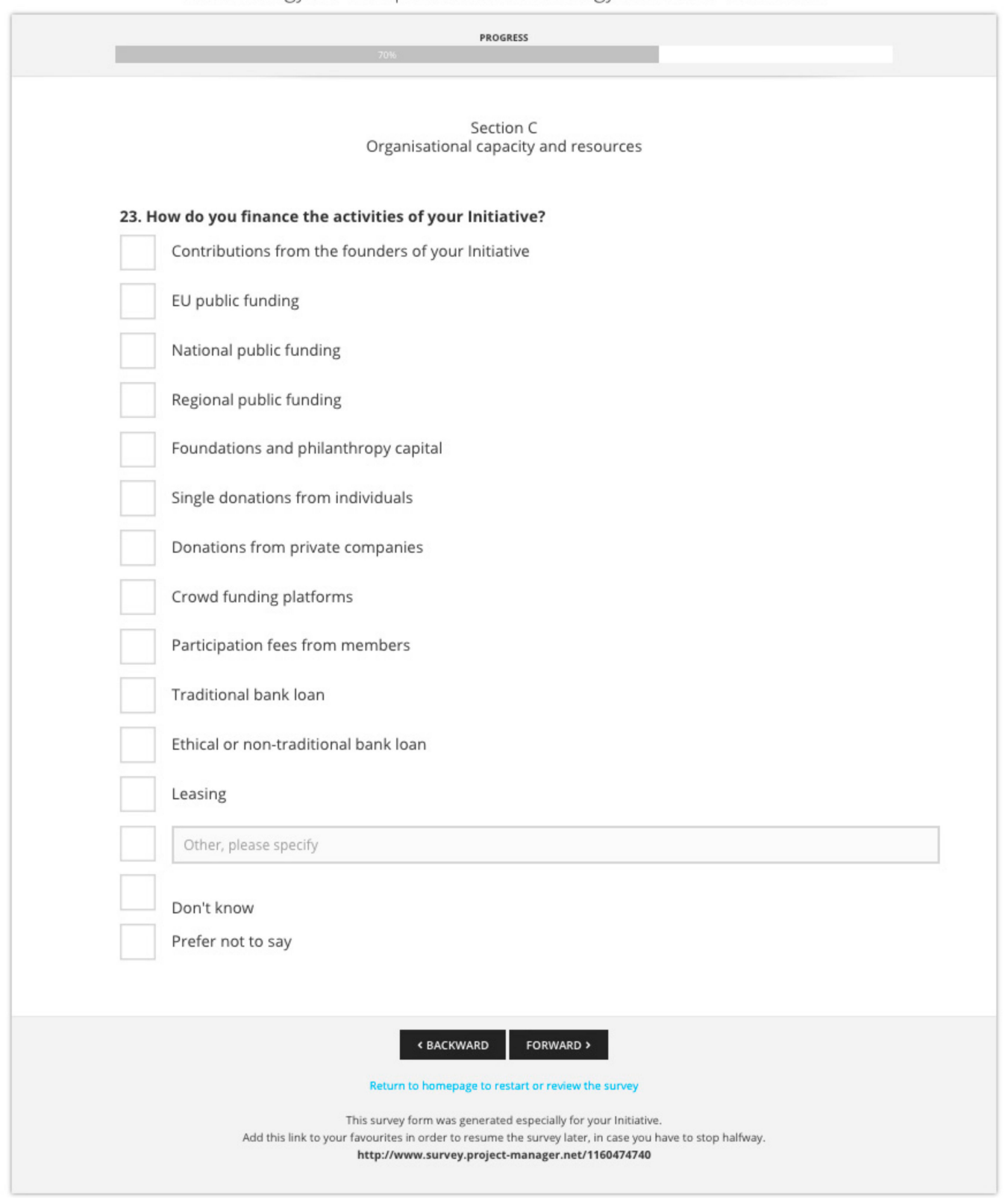

Figure A4. Question 23 of the survey form.

\section{References}

1. European Commission Commission Proposes New Rules for Consumer Centred Clean Energy Transition. Available online: https://ec.europa.eu/energy/en/news/commission-proposes-new-rules-consumer-centredclean-energy-transition (accessed on 25 April 2019).

2. European Commission Clean Energy for All Europeans Package Completed: Good for Consumers, Good for Growth and Jobs, and Good for the Planet. Available online: https://ec.europa.eu/info/news/clean-energy-alleuropeans-package-completed-good-consumers-good-growth-and-jobs-and-good-planet-2019-may-22_en (accessed on 28 May 2019).

3. European Parliament and Council of the European Union DIRECTIVE (EU) 2019/944 OF THE EUROPEAN PARLIAMENT AND OF THE COUNCIL of 5 June 2019 on Common Rules for the Internal Market for Electricity and Amending Directive 2012/27/EU (Recast). Available online: https://eur-lex.europa.eu/legalcontent/EN/TXT/?qid=1570285915486\&uri=CELEX:32019L0944 (accessed on 5 October 2019). 
4. European Commission. The State of the Energy Union Explained; Fact sheet; European Commission: Brussels, Belgium, 2019; p. 5.

5. European Parliament and Council Directive (EU) 2018/2001 of the European Parliament and of the Council of 11 December 2018 on the Promotion of the Use of Energy from Renewable Sources. Available online: https://eur-lex.europa.eu/legal-content/EN/TXT/?uri=uriserv\%3AOJ.L_.2018.328.01.0082.01.ENG\& toc $=$ OJ\%3AL\%3A2018\%3A328\%3ATOC (accessed on 13 March 2019).

6. Ford, R.; Stephenson, J.; Whitaker, J. Prosumer Collectives: A Review; New Zealand's Smart Grid Forum, Centre for Sustainability; University of Otago: Dunedin, New Zealand, 2016; pp. 1-28.

7. Bertram, R.; Primova, R. (Eds.) ENERGY ATLAS 2018: Facts and Figures About Renewables in Europe; Heinrich Böll Foundation, FOEE, EREF, GEF: Luxembourg, 2018; p. 56.

8. Huybrechts, B.; Haugh, H. The Roles of Networks in Institutionalizing New Hybrid Organizational Forms: Insights from the European Renewable Energy Cooperative Network. Organ. Stud. 2018, 39, 1085-1108. [CrossRef]

9. Lavrijssen, S.; Carrillo Parra, A. Radical Prosumer Innovations in the Electricity Sector and the Impact on Prosumer Regulation. Sustainability 2017, 9, 1207. [CrossRef]

10. Toporek, M.; Campos, I.S. Assessment of Existing EU-Wide and Member State-Specific Regulatory and Policy Frameworks of RES Prosumers (Deliverable N³.1); ClientEarth: Brussels, Belgium, 2019; p. 128.

11. Haggett, C.; Creamer, E.; Harnmeijer, J.; Parsons, M.; Bomberg, E. Community energy in Scotland: The Social Factors for Success; University of Edinburgh: Edinburgh, UK, 2013; p. 25.

12. Dóci, G.K. Renewable Energy Communities. A Comprehensive Study of Local Energy Initiatives in the Netherlands and Germany. Ph.D. Thesis, Vrije Universiteit Amsterdam, Amsterdam, The Netherlands, 2017.

13. Dóci, G.; Vasileiadou, E.; Petersen, A.C. Exploring the transition potential of renewable energy communities. Futures 2015, 66, 85-95. [CrossRef]

14. Smith, A.; Hargreaves, T.; Hielscher, S.; Martiskainen, M.; Seyfang, G. Making the most of community energies: Three perspectives on grassroots innovation. Environ. Plan A 2016, 48, 407-432. [CrossRef]

15. Walker, G.; Devine-Wright, P.; Hunter, S.; High, H.; Evans, B. Trust and community: Exploring the meanings, contexts and dynamics of community renewable energy. Energy Policy 2010, 38, 2655-2663. [CrossRef]

16. Lacey-Barnacle, M.; Bird, C.M. Intermediating energy justice? The role of intermediaries in the civic energy sector in a time of austerity. Appl. Energy 2018, 226, 71-81. [CrossRef]

17. Soares, M.; Brown, D.; Gährs, S.; Horstink, L.; Novosel, T.; Oxenaar, S.; Petrick, K.; Puksec, T.; Toporek, M. PROSEU Renewable Energy Country Fact Sheets; University of Porto: Porto, Portugal, 2019; p. 20. Available online: https://zenodo.org/record/3247376\#.XfZ9yOvgp0w (accessed on 5 October 2019).

18. Gross, R.; Hanna, R. Path dependency in provision of domestic heating. Nat. Energy 2019, 4, 358-364. [CrossRef]

19. Wirth, S. Communities matter: Institutional preconditions for community renewable energy. Energy Policy 2014, 70, 236-246. [CrossRef]

20. Romero-Rubio, C.; de Andrés Díaz, J.R. Sustainable energy communities: A study contrasting Spain and Germany. Energy Policy 2015, 85, 397-409. [CrossRef]

21. Statistical Office of the European Union. EUROSTAT: SHARES 2017-Short Assessment of Renewable Energy Sources; Eurostat: Brussels, Belgium, 2019.

22. Campos, I.; Pontes Luz, G.; Marín-González, E.; Gährs, S.; Hall, S.; Holstenkamp, L. Regulatory challenges and opportunities for collective renewable energy prosumers in the EU. Energy Policy 2019, in press.

23. Horstink, L.; Luz, G.P.; Soares, M.; Ng, K. Review and Characterisation of Collective Renewable Energy Prosumer Initiatives; University of Porto: Porto, Portugal, 2019; p. 156.

24. Butenko, A.; Cseres, K. The Regulatory Consumer: Prosumer-Driven Local Energy Production Initiatives; Social Science Research Network: Rochester, NY, USA, 2015.

25. Butenko, A. User-Centered Innovation and Regulatory Framework: Energy Prosumers' Market Access in EU Regulation; Social Science Research Network: Rochester, NY, USA, 2016.

26. Howaldt, J.; Schröder, A.; Kaletka, C.; Rehfeld, D.; Terstriep, J. Mapping the World of Social Innovation: A Global Comparative Analysis Across Sectors and World Regions; Technische Universität Dortmund: Dortmund, Germany, 2016.

27. Bauwens, T.; Gotchev, B.; Holstenkamp, L. What drives the development of community energy in Europe? The case of wind power cooperatives. Energy Res. Soc. Sci. 2016, 13, 136-147. [CrossRef] 
28. Bauwens, T. Explaining the diversity of motivations behind community renewable energy. Energy Policy 2016, 93, 278-290. [CrossRef]

29. Hewitt, R.J.; Bradley, N.; Baggio Compagnucci, A.; Barlagne, C.; Ceglarz, A.; Cremades, R.; McKeen, M.; Otto, I.M.; Slee, B. Social Innovation in Community Energy in Europe: A Review of the Evidence. Front. Energy Res. 2019, 7, 31. [CrossRef]

30. Brummer, V. Community energy-benefits and barriers: A comparative literature review of Community Energy in the UK, Germany and the USA, the benefits it provides for society and the barriers it faces. Renew. Sustain. Energy Rev. 2018, 94, 187-196. [CrossRef]

31. Vansintjan, D. The Energy Transition to Energy Democracy —Power to the People; REScoop.eu: Antwerp, Belgium, 2015; p. 76.

32. Bauwens, T.; Devine-Wright, P. Positive energies? An empirical study of community energy participation and attitudes to renewable energy. Energy Policy 2018, 118, 612-625. [CrossRef]

33. Clancy, J.; Daskalova, V.; Feenstra, M.; Franceschelli, N. Gender Perspective on Access to Energy in the EU; European Union: Brussels, Belgium, 2017; p. 106.

34. European Institute for Gender Equality. Gender and Energy; Publications Office of the European Union: Luxembourg, 2016.

35. Mort, H. A Review of Energy and Gender Research in the Global North; Technical University of Vienna: Vienna, Austria, 2019.

36. Seyfang, G.; Smith, A. Grassroots innovations for sustainable development: Towards a new research and policy agenda. Environ. Politics 2007, 16, 584-603. [CrossRef]

37. Seyfang, G.; Hielscher, S.; Hargreaves, T.; Martiskainen, M.; Smith, A. A grassroots sustainable energy niche? Reflections on community energy in the UK. Environ. Innov. Soc. Transit. 2014, 13, 21-44. [CrossRef]

38. Koirala, B.P.; Koliou, E.; Friege, J.; Hakvoort, R.A.; Herder, P.M. Energetic communities for community energy: A review of key issues and trends shaping integrated community energy systems. Renew. Sustain. Energy Rev. 2016, 56, 722-744. [CrossRef]

39. Parag, Y.; Sovacool, B.K. Electricity market design for the prosumer era. Nat. Energy 2016, 1, 16032. [CrossRef]

40. Wierling, A.; Schwanitz, V.J.; Zeiß, J.P.; Bout, C.; Candelise, C.; Gilcrease, W.; Gregg, J.S. Statistical Evidence on the Role of Energy Cooperatives for the Energy Transition in European Countries. Sustainability 2018, 10, 3339. [CrossRef]

41. Soeiro, S.; Ferreira Dias, M. Energy cooperatives in southern European countries: Are they relevant for sustainability targets? Energy Rep. 2019, in press. [CrossRef]

42. Mapa Interactivo-Socio Unión Renovables Coop. Unión Renovables. Available online: http://www. unionrenovables.coop/mapa-interactivo/ (accessed on 15 December 2019).

43. Mautz, R.; Byzio, A.; Rosenbaum, W. Auf dem Weg zur Energiewende: Die Entwicklung der Stromproduktion aus erneuerbaren Energien in Deutschland; eine Studie aus dem Soziologischen Forschungsinstitut Göttingen (SOFI); Universitätsverlag Göttingen: Göttingen, Germany, 2008; ISBN 978-3-938616-98-7.

44. Fraune, C. Gender matters: Women, renewable energy, and citizen participation in Germany. Energy Res. Soc. Sci. 2015, 7, 55-65. [CrossRef]

45. Bauwens, T.; Eyre, N. Exploring the links between community-based governance and sustainable energy use: Quantitative evidence from Flanders. Ecol. Econ. 2017, 137, 163-172. [CrossRef]

46. Pahl-Wostl, C. Participative and Stakeholder-Based Policy Design, Evaluation and Modeling Processes. Integr. Assess. 2002, 3, 3-14. [CrossRef]

47. Raven, R. Niche accumulation and hybridisation strategies in transition processes towards a sustainable energy system: An assessment of differences and pitfalls. Energy Policy 2007, 35, 2390-2400. [CrossRef]

48. Bauwens, T.; Huybrechts, B.; Dufays, F. Understanding the Diverse Scaling Strategies of Social Enterprises as Hybrid Organizations: The Case of Renewable Energy Cooperatives. Organ. Environ. 2019. [CrossRef]

49. Blanco, M.I. The economics of wind energy. Renew. Sustain. Energy Rev. 2009, 13, 1372-1382. [CrossRef]

50. Malinowski, M.; Leon, J.I.; Abu-Rub, H. Solar Photovoltaic and Thermal Energy Systems: Current Technology and Future Trends. Proc. IEEE 2017, 105, 2132-2146. [CrossRef]

51. Gil-Lacruz, A.I.; Marcuello, C.; Saz-Gil, M.I. Gender differences in European volunteer rates. J. Gend. Stud. 2019, 28, 127-144. [CrossRef]

52. Kahla, F. Die Kapitalstruktur von Bürgerenergiegesellschaften unter dem rechtlichen Rahmenwerk der deutschen Energiewende. Zeitschrift Umweltpolitik Umweltrecht 2019, 2019, 94-123. 
53. Holstenkamp, L.; Kahla, F.; Degenhart, H. Finanzwirtschaftliche Annäherungen an das Phänomen Bürgerbeteiligung. In Handbuch Energiewende und Partizipation; Holstenkamp, L., Radtke, J., Eds.; Springer Fachmedien: Wiesbaden, Germany, 2018; pp. 281-301. ISBN 978-3-658-09416-4.

54. Holstenkamp, L. Financing Consumer (Co-) Ownership of Renewable Energy Sources. In Energy Transition: Financing Consumer Co-Ownership in Renewables; Lowitzsch, J., Ed.; Springer International Publishing: Cham, Switzerland, 2019; pp. 115-138. ISBN 978-3-319-93518-8.

55. Valeau, P.J. Stages and Pathways of Development of Nonprofit Organizations: An Integrative Model. Voluntas 2015, 26, 1894-1919. [CrossRef]

56. Sundblom, D.; Smith, D.H.; Selle, P.; Dansac, C.; Jensen, C. Life Cycles of Individual Associations. In The Palgrave Handbook of Volunteering, Civic Participation, and Nonprofit Associations; Smith, D.H., Stebbins, R.A., Grotz, J., Eds.; Palgrave Macmillan: London, UK, 2016; pp. 950-971. ISBN 978-1-137-26317-9.

57. DiMaggio, P.J.; Powell, W.W. The Iron Cage Revisited: Institutional Isomorphism and Collective Rationality in Organizational Fields. Am. Sociol. Rev. 1983, 48, 147-160. [CrossRef]

58. Anheier, H.K. Nonprofit Organizations: Theory, Management, Policy, 2nd ed.; Routledge: Abingdon, UK, 2014; ISBN 978-0-415-55046-8.

59. Billis, D. Hybrid Associations and Blurred Sector Boundaries. In The Palgrave Handbook of Volunteering, Civic Participation, and Nonprofit Associations; Smith, D.H., Stebbins, R.A., Eds.; Palgrave Macmillan: London, UK, 2016; pp. 206-220. ISBN 978-1-137-26317-9.

60. Marquez, L.M.M. The Relevance of Organizational Structure to NGOs' Approaches to the Policy Process. Voluntas 2016, 27, 465-486. [CrossRef]

61. Markowitz, L.; Tice, K.W. Paradoxes of Professionalization: Parallel Dilemmas in Women's Organizations in the Americas. Gend. Soc. 2002, 16, 941-958. [CrossRef]

62. Cumming, G.D. French NGOs in the Global Era: Professionalization "Without Borders"? Voluntas 2008, 19, 372-394. [CrossRef]

63. Rothschild, J.; Chen, K.K.; Smith, D.H.; Kristmundsson, O. Avoiding Bureaucratization and Mission Drift in Associations. In The Palgrave Handbook of Volunteering, Civic Participation, and Nonprofit Associations; Smith, D.H., Stebbins, R.A., Grotz, J., Eds.; Palgrave Macmillan: London, UK, 2016; pp. 1007-1024. ISBN 978-1-137-26317-9.

64. Sander, C. Kooperationen in der Energiewirtschaft. Eine empirische Analyse Kommunaler Energieversorgungsunternehmen [Cooperations in the Power Industry. An Empirical Analysis of Municipal Utilities]. Ph.D. Thesis, University of Münster, Münster, Germany, 2011.

65. Lütjen, H.; Tietze, F.; Nuske, T. Innovationskooperationen von Stadtwerken: Eine empirische Untersuchung von Treibern und Barrieren; BoD—Books on Demand: Norderstedt, Germany, 2014; ISBN 978-3-7357-4710-5.

66. Jansen, D.; Heidler, R. Shareholding and Cooperation among Local Utilities: Driving Factors and Effects. In Sustainability Innovations in the Electricity Sector; Jansen, D., Ostertag, K., Walz, R., Eds.; Sustainability and Innovation; Physica-Verlag HD: Heidelberg, Germany, 2012; pp. 57-81. ISBN 978-3-7908-2730-9.

(C) 2020 by the authors. Licensee MDPI, Basel, Switzerland. This article is an open access article distributed under the terms and conditions of the Creative Commons Attribution (CC BY) license (http://creativecommons.org/licenses/by/4.0/). 